\title{
Mercury mobility, colloid formation and methylation in a polluted Fluvisol as affected by manure application and flooding-draining cycle
}

\author{
Lorenz Gfeller ${ }^{1}$, Andrea Weber ${ }^{1}$, Isabelle Worms ${ }^{2}$, Vera I. Slaveykova ${ }^{2}$, and Adrien Mestrot ${ }^{1}$ \\ ${ }^{1}$ Institute of Geography, University of Bern, Hallerstrasse 12, 3012 Bern, Switzerland \\ ${ }^{2}$ Environmental Biogeochemistry and Ecotoxicology, Department F.-A. Forel for environmental and aquatic sciences, \\ School of Earth and Environmental Sciences, Faculty of Sciences, University of Geneva, Uni Carl Vogt, \\ Bvd Carl-Vogt 66, 1211 Geneva 4, Switzerland
}

Correspondence: Adrien Mestrot (adrien.mestrot@giub.unibe.ch)

Received: 11 December 2020 - Discussion started: 1 February 2021

Revised: 23 April 2021 - Accepted: 2 May 2021 - Published: 10 June 2021

\begin{abstract}
Floodplain soils polluted with high levels of mercury $(\mathrm{Hg})$ are potential point sources to downstream ecosystems. Repeated flooding (e.g., redox cycling) and agricultural activities (e.g., organic matter addition) may influence the fate and speciation of $\mathrm{Hg}$ in these soil systems. The formation and aggregation of colloids and particles influence both $\mathrm{Hg}$ mobility and its bioavailability to microbes that form methylmercury ( $\mathrm{MeHg}$ ). In this study, we conducted a microcosm flooding-draining experiment on $\mathrm{Hg}$-polluted floodplain soils originating from an agriculturally used area situated in the Rhone Valley (Valais, Switzerland). The experiment comprised two $14 \mathrm{~d}$ flooding periods separated by one $14 \mathrm{~d}$ draining period. The effect of freshly added natural organic matter on $\mathrm{Hg}$ dynamics was assessed by adding liquid cow manure ( $+\mathrm{MNR}$ ) to two soils characterized by different $\mathrm{Hg}\left(47.3 \pm 0.5\right.$ or $\left.2.38 \pm 0.01 \mathrm{mg} \mathrm{kg}^{-1}\right)$ and organic carbon (OC: $1.92 \mathrm{wt} \%$ or $3.45 \mathrm{wt} \%$ ) contents. During the experiment, the release, colloid formation of $\mathrm{Hg}$ in soil solution and net $\mathrm{MeHg}$ production in the soil were monitored. Upon manure addition in the highly polluted soil (lower OC), an accelerated release of $\mathrm{Hg}$ to the soil solution could be linked to a fast reductive dissolution of Mn oxides. The manure treatments showed a fast sequestration of $\mathrm{Hg}$ and a higher percentage of $\mathrm{Hg}$ bound by particulate $(0.02-10 \mu \mathrm{m})$. Also, analyses of soil solutions by asymmetrical flow field-flow fractionation coupled with inductively coupled plasma mass spectrometry (AF4-ICP-MS) revealed a relative increase in colloidal $\mathrm{Hg}$ bound to dissolved organic matter (Hg-DOM)
\end{abstract}

and inorganic colloidal $\mathrm{Hg}(70 \%-100 \%)$ upon manure addition. Our experiment shows a net $\mathrm{MeHg}$ production the first flooding and draining period and a subsequent decrease in absolute $\mathrm{MeHg}$ concentrations after the second flooding period. Manure addition did not change net $\mathrm{MeHg}$ production significantly in the incubated soils. The results of this study suggest that manure addition may promote $\mathrm{Hg}$ sequestration by $\mathrm{Hg}$ complexation on large organic matter components and the formation and aggregation of inorganic $\mathrm{HgS}_{(\mathrm{s})}$ colloids in $\mathrm{Hg}$-polluted Fluvisols with low levels of natural organic matter.

\section{Introduction}

Mercury $(\mathrm{Hg})$ is a pollutant of global concern due to its high toxicity and to its global biogeochemical cycle which spans all environmental compartments (atmosphere, oceans, soils, etc.) (Beckers and Rinklebe, 2017; AMAP/UN Environment, 2019). Sediments and soils are major $\mathrm{Hg}$ pools with relatively long residence times (Amos et al., 2013; Driscoll et al., 2013). Legacy Hg from industrial sites (e.g., chlor-alkali plants or mining areas) retained in soils is a key source for present-day atmospheric $\mathrm{Hg}$ (Amos et al., 2013). However, this retained $\mathrm{Hg}$ pool can also be remobilized by landscape alteration, land use (e.g., fertilization, manure addition) or climate-induced changes such as drought-flood-drought cycles of soils (Singer et al., 2016). These inputs are a threat to 
downstream ecosystems and human health due to release of inorganic $\mathrm{Hg}$ and the formation and bioaccumulation of toxic monomethylmercury ( $\mathrm{MeHg}$ ) in both aquatic and terrestrial food chains (Bigham et al., 2017).

Mercury is redox sensitive and occurs mainly as elemental $\mathrm{Hg}^{0}$, inorganic $\mathrm{Hg}^{2+}$ or in the form of MeHg in soils. In general, $\mathrm{Hg}$ speciation in soils depends on the biogeochemical conditions. For example, in boreal peatlands and forest soils rich in natural organic matter (NOM), $\mathrm{Hg}$ is primarily bound to thiol groups of NOM (NOM-Hg), associated with $\mathrm{FeS}_{(\mathrm{s})}$ or found as cinnabar $\left(\mathrm{HgS}_{(\mathrm{s})}\right)$ or metacinnabar $\left(\beta-\mathrm{HgS}_{(\mathrm{s})}\right)$. These species are the thermodynamically most favored forms of $\mathrm{Hg}$ in these environments (Skyllberg et al., 2006; Skyllberg and Drott, 2010; Biester et al., 2002). However, $\mathrm{Hg}$ sorbed on the surfaces of manganese $(\mathrm{Mn})$, iron (Fe) and aluminum (Al) oxy-hydroxides may also represent important $\mathrm{Hg}$ pools in soils with low amounts of NOM (Guedron et al., 2009).

The fate of $\mathrm{Hg}$ in soils is still not well characterized, and its mobilization and sequestration in soil depend on a variety of factors and mechanisms. The release of $\mathrm{Hg}$ to the soil solution and its further transport have been associated with the mobilization of NOM (Kronberg et al., 2016; Eklöf et al., 2018; Åkerblom et al., 2008), copper ( $\mathrm{Cu})$ nanoparticles (Hofacker et al., 2013) or the reductive dissolution of Fe / Mn oxyhydroxides (Frohne et al., 2012; Gygax et al., 2019; Poulin et al., 2016). Earlier studies reported a relatively rapid decrease in dissolved $\mathrm{Hg}$ after its release upon flooding in various riparian settings (Hofacker et al., 2013; Poulin et al., 2016; Gygax et al., 2019). Possible pathways for this decrease are $\mathrm{Hg}^{2+}$ reduction to $\mathrm{Hg}^{0}$, sorption to recalcitrant NOM, formation of metacinnabar $\beta-\mathrm{HgS}_{(\mathrm{s})}$ or coprecipitation of $\mathrm{Hg}$ in sulfides (e.g., $\mathrm{FeS}_{(\mathrm{s})}$ ) or metallic particles.

Metallic colloids in soil may be formed by biomineralization during soil reduction or precipitation in the root zone and potentially incorporate toxic trace elements like $\mathrm{Hg}$ (Weber et al., 2009; Manceau et al., 2008). These colloids may increase the mobility and persistence of toxic trace metals in soil solution if they do not aggregate to bigger particles. During a flooding incubation experiment, Hofacker et al. (2013) observed the incorporation of $\mathrm{Hg}$ in $\mathrm{Cu}$ nanoparticles, which were shown to be formed by fermentative bacteria species (Hofacker et al., 2015). Colloidal $\beta-\mathrm{HgS}_{(\mathrm{s})}$ has been reported to form abiotically in soils under oxic conditions directly by interaction with thiol groups of NOM (Manceau et al., 2015). In solution, dissolved organic matter (DOM) has a major influence in the formation and aggregation of metallic colloids and particles. It may promote the dissolution of $\mathrm{HgS}_{(\mathrm{s})}$ phases, decelerate the aggregation and growth of $\mathrm{HgS}_{(\mathrm{s})}$ colloids, and affect the crystallinity of $\mathrm{HgS}_{(\mathrm{s})}$ phases (Miller et al., 2007; Ravichandran et al., 1998; Gerbig et al., 2011; Poulin et al., 2017; Pham et al., 2014). The same effects were also observed for other metal sulfide, oxide or carbonate colloids (Aiken et al., 2011; Deonarine et al., 2011). In the case of $\mathrm{Hg}$, inhibition of $\beta-\mathrm{HgS}_{(\mathrm{s})}$ formation may in turn increase its mobility and bioavailability to $\mathrm{MeHg}$-producing microorganisms (Deonarine and Hsu-Kim, 2009; Ravichandran et al., 1999; Aiken et al., 2011; Graham et al., 2012). Chelation of $\mathrm{Hg}$ with higher-molecular-weight NOM may also inhibit the microbial availability of $\mathrm{Hg}$ (Bravo et al., 2017). Within Hg-NOM, hydrophobic, thiol-rich NOM with higher molecular weight contains a higher density of strong sorption sites (thiol groups) (Haitzer et al., 2002). However, different ligand exchange reactions (e.g., carboxyl groups to thiol groups) kinetically control this sorption and thus the bioavailability of dissolved $\mathrm{Hg}$ in aqueous systems (Miller et al., 2007, 2009; Liang et al., 2019). The partly contradicting statements above illustrate the complex role of NOM and DOM in the $\mathrm{Hg}$ cycle and $\mathrm{Hg}$ bioavailability and the need for more research in this field.

The formation of $\mathrm{MeHg}$ from inorganic $\mathrm{Hg}^{2+}$ has been shown to be primarily microbially driven. Environments of redox oscillation (e.g., floodplains, estuaries) represent hotspots for $\mathrm{Hg}$ methylation (Marvin-DiPasquale et al., 2014; Bigham et al., 2017). Mercury methylators are usually anaerobe microbial species such as sulfate reducers (SRB), Fe reducers (FeRB), archaea and some firmicutes (Gilmour et al., 2013). Generally, $\mathrm{Hg}$ is bioavailable to methylators in the form of dissolved $\mathrm{Hg}^{2+}, \mathrm{Hg}$ complexed by labile DOM or $\mathrm{Hg}$-bearing inorganic nanoparticles (e.g., $\mathrm{FeS}_{(\mathrm{s})}, \mathrm{HgS}_{(\mathrm{s})}$ ) but is less available when complexed by particulate organic matter (Hg-POM) or larger inorganic particles (Chiasson-Gould et al., 2014; Graham et al., 2013; Rivera et al., 2019; Zhang et al., 2012; Jonsson et al., 2012). Further, DOM is a main driver of $\mathrm{Hg}$ methylation as it influences both bioavailability and microbial activity. The role of DOM as an electron donor may enhance the microbial activity and thus the cellular uptake. The composition and origin of DOM were reported to change $\mathrm{Hg}$ methylation rates (Drott et al., 2007; Bravo et al., 2017). For example, Bravo et al. (2017) showed that in lake sediments, terrestrially derived DOM led to slower methylation rates than phytoplankton-derived DOM. The addition of DOM in the form of organic amendments (e.g., manure, rice straw, biochar) has been reported to have both an enhancing effect (Gygax et al., 2019; Liu et al., 2016; Wang et al., 2019; Eckley et al., 2021; Wang et al., 2020) and no effect (Zhu et al., 2016; Liu et al., 2016) on the net MeHg production in soils. Further, organic amendments were reported to shift microbial communities. Both the enhancement of $\mathrm{Hg}$ demethylators and $\mathrm{Hg}$ reducers ( $\mathrm{Hu}$ et al., 2019) and the enhancement of $\mathrm{Hg}$ methylators upon organic amendments were reported (Tang et al., 2019; Wang et al., 2020). Environments of elevated $\mathrm{Hg}$ methylation (riparian zone, estuary) are also places of elevated NOM degradation and mineralization due to temporal changes in redox conditions. The degradation of large NOM to more bioavailable low-molecularweight (LMW) compounds promoted by microbial Mn oxidation, especially in systems with neutral pH (Jones et al., 2018; Sunda and Kieber, 1994; Ma et al., 2020), is also hy- 
pothesized to increase bioavailability of $\mathrm{Hg}-\mathrm{NOM}$. However, amendments of $\mathrm{Mn}$ oxides were also shown to inhibit $\mathrm{Fe}$ - and $\mathrm{SO}_{4}^{2-}$-reducing conditions and thus $\mathrm{MeHg}$ formation in sediments (Vlassopoulos et al., 2018).

$\mathrm{Hg}$ methylation and mobilization is intensively studied in paddy field soils and peat soils due to their relevance in food production or the Hg global cycle (Wang et al., 2019; Tang et al., 2018; Liu et al., 2016; Hu et al., 2019; Wang et al., 2016; Zhao et al., 2018; Zhu et al., 2016; Kronberg et al., 2016; Skyllberg, 2008; Skyllberg et al., 2006). However, only a few studies focused on $\mathrm{Hg}$ methylation and mobility in temperate floodplain soils (Frohne et al., 2012; Hofacker et al., 2013; Gilli et al., 2018; Poulin et al., 2016; Lazareva et al., 2019; Wang et al., 2020; Beckers et al., 2019). Also, few studies have examined the effect of flooding and/or land use (NOM addition in the form of animal manure) in polluted soils with respect to $\mathrm{Hg}$ release and methylation potential (Tang et al., 2018; Gygax et al., 2019; Zhang et al., 2018; Hofacker et al., 2013; Frohne et al., 2012). Furthermore, most of these studies were focusing on soils with rather high OC levels ( $5 \mathrm{wt} \%-10 \mathrm{wt} \%$ ), and only few researchers have addressed the decrease in $\mathrm{Hg}$ in soil solution of flooded soils over time, including the fate of colloidal $\mathrm{Hg}$.

This work focused on the effect of agricultural practices on the $\mathrm{Hg}$ mobility and methylation in a real-world contaminated Fluvisol with specific emphasis on the floodingdraining cycle and manure addition. By conducting microcosm experiments, we studied the effect of these cycles and manure addition on (1) the release and sequestration of $\mathrm{Hg}$, (2) the methylation of $\mathrm{Hg}$ and (3) the evolution of colloidal and particulate $\mathrm{Hg}$ in soil solution. The latter was studied by analyzing different soil solution filter fractions ( 0.02 and $10 \mu \mathrm{m})$ as well as analyzing selected samples by asymmetric flow field-flow fractionation coupled to a $\mathrm{UV}_{\text {vis }}$ detector, a fluorescence detector and an ICP-MS (AF4-ICP-MS). Based on the presented state of knowledge, we hypothesize that the manure addition would accelerate the release of $\mathrm{Hg}$ by accelerated reductive dissolution of $\mathrm{Mn}$ oxyhydroxides in these soils and eventually change $\mathrm{Hg}$ speciation in the system towards $\mathrm{Hg}-\mathrm{NOM}$ complexes and $\beta$ - $\mathrm{HgS}_{(\mathrm{s})}$ colloids.

\section{Methods and materials}

\subsection{Sample collection}

We sampled soil from agriculturally used fields in the alpine Rhone Valley in Wallis, Switzerland, on 30 September 2019. The fields are situated in a former floodplain next to the artificial "Grossgrundkanal" canal. This canal was built in the 1900s to drain the floodplain and as a buffer for the wastewater releases of a chemical plant upstream that historically used $\mathrm{Hg}$ in different processes (chlor-alkali electrolysis, acetaldehyde and vinyl chloride production). The soils on the floodplain were subjected to $\mathrm{Hg}$ pollution from this plant be- tween the 1930s and the 1970s, mostly through the removal and dispersion of the canal sediments onto the agricultural fields (Glenz and Escher, 2011). After heavy rain events, the fields are subjected to draining-flooding cycles (Fig. S1 in the Supplement) and have been identified as potential hotspots for $\mathrm{Hg}$ methylation and release (Gygax et al., 2019). For this study, soil was sampled from a cornfield and a pasture field next to the canal. A map and the coordinates of the sampling locations are provided in the Supplement (Fig. S1, Table S1 in the Supplement). At each site, a composite sample of approximately $10 \mathrm{~kg}$ of soil was sampled between 0 $20 \mathrm{~cm}$ depth from 10 points on the fields. The soil samples were named after their relative pollution and organic carbon levels (high mercury, low carbon (HMLC) and low mercury, high carbon (LMHC); see Sect. 2.4 below for details on the soils). After sampling, roots were removed, and the fresh soil was sieved to $<2 \mathrm{~mm}$ grain size, further homogenized, split in two parts and stored on ice in airtight PE bags for transport to the laboratory. Additionally, approximately $2 \mathrm{~L}$ of liquid cow manure was sampled from a close-by cattle farm. One aliquot of the samples was stored at $-20^{\circ} \mathrm{C}$ until further processing. The remaining part was used for the incubation experiment within $12 \mathrm{~h}$ after sampling. A detailed description of the site and sampling procedures is given in the Supplement (Sect. S1).

\subsection{Microcosm experiments}

An initial incubation was conducted in 10L HDPE containers in the dark for $7 \mathrm{~d}$ in an atmosphere of $22^{\circ} \mathrm{C}$ and $60 \%$ relative humidity $(\mathrm{RH})$ in order to equilibrate the soils and to prevent a peak of microbial respiration induced by the soil sieving before the onset of the experiment (Fig. 1). After the initial incubation period soils were used in the flooding and draining experiments, which were conducted in $1 \mathrm{~L}$ borosilicate glass aspirator bottles (Fig. S2). The environment created through soil flooding in these bottles will be called the microcosm (MC) in the following text. Microcosm experiments were performed in experimental triplicate and named after the relative $\mathrm{Hg}$ and organic carbon levels of the used soil (HMLC and LMHC) and the treatment with or without manure addition (added + MNR). The microcosms were equipped with an acid-washed suction cup with a pore size of $<10 \mu \mathrm{m}$ (model: 4313.7/ETH, ecoTech Umwelt-Meßsysteme $\mathrm{GmbH}$, Bonn, Germany). In the following sequence, $700 \mathrm{~g}$ of artificial rainwater $\left(\mathrm{NH}_{4} \mathrm{NO}_{3} \quad 11.6 \mathrm{mg} \mathrm{L}^{-1} / \mathrm{K}_{2} \mathrm{SO}_{4}\right.$ $7.85 \mathrm{mg} \mathrm{L}^{-1} / \mathrm{Na}_{2} \mathrm{SO}_{4} \quad 1.11 \mathrm{mg} \mathrm{L}^{-1} / \mathrm{MgSO}_{4} \cdot 7 \mathrm{H}_{2} \mathrm{O}$ $1.31 \mathrm{mg} \mathrm{L}^{-1} / \mathrm{CaCl}_{2} 4.32 \mathrm{mg} \mathrm{L}^{-1}$ ) was added to the microcosms. For the manure treatment, $0.6 \%(w / w)(3 \mathrm{~g})$ of liquid cow manure was added to the microcosms corresponding to one application of liquid manure on a cornfield following the principles of fertilization of agricultural crops in Switzerland (Richner and Sinaj, 2017), and finally fresh soil was added with a soil $\mathrm{dry}_{\mathrm{f}}$ : water ratio of $1: 1.4(w / w)$ 
(Fig. S3). Then, the microcosms were gently shaken for at least 1 min to remove any remaining air bubbles in the soil and pore space. An additional mixture of fresh soil artificial rainwater $(1: 1.4(w / w))$ was shaken for $6 \mathrm{~h}$ to assess the equilibration of the solid and liquid phases during the experiment. The microcosms were covered with Parafilm ${ }^{\circledR}$, transferred to the incubation chamber (APT.line ${ }^{\mathrm{TM}} \mathrm{KBWF}$, Binder, Tuttlingen, Germany) and incubated in the dark for $14 \mathrm{~d}$ in an atmosphere of $22{ }^{\circ} \mathrm{C}$ and $60 \% \mathrm{RH}$. The incubation temperature was chosen to be close to the daily mean soil temperature at $10 \mathrm{~cm}$ depth during summer months between $2015-2019\left(21.4^{\circ} \mathrm{C}\right)$ at the closest soil temperature monitoring station (Sion, VS, provided by MeteoSwiss) situated downstream. After the first flooding period, the supernatant water was pipetted off, and remaining water was sampled through the suction cups to drain the microcosms. They were weighted before and after water removal. Then, approximately $25 \mathrm{~g}$ of moist soil was sampled by two to three scoops though the whole soil column using a disposable lab spoon. The microcosms were kept drained in an atmosphere of $22^{\circ} \mathrm{C}$ and $10 \% \mathrm{RH}$ for $14 \mathrm{~d}$. For the second flooding period, the microcosms were again flooded with $500 \mathrm{~g}$ of artificial rainwater and incubated for another $14 \mathrm{~d}$ in an atmosphere of $22{ }^{\circ} \mathrm{C}$ and $60 \% \mathrm{RH}$ (Fig. 1). After the incubation, the suction cups were removed, and the soils were homogenized and then transferred from the $\mathrm{MC}$ to a $\mathrm{PE}$ bag and stored at $-20^{\circ} \mathrm{C}$ until further processing.

\subsection{Soil and manure characterization}

Frozen soil and manure samples were freeze dried to avoid a loss of $\mathrm{Hg}$ prior to analyses (Hojdová et al., 2015), ground using an automatic ball mill (MM400, Retsch, Haan, Germany) and analyzed for the following chemical parameters. Carbon (C), nitrogen $(\mathrm{N})$ and sulfur (S) were measured with an elemental analyzer (vario EL cube, Elementar Analysensysteme, Langenselbold, Germany). Organic carbon (OC) was calculated by subtracting the $\mathrm{C}$ concentration of a loss-on-ignition sample $\left(550^{\circ} \mathrm{C}\right.$ for $\left.2 \mathrm{~h}\right)$ from the original $\mathrm{C}$ concentration. The $\mathrm{pH}$ was measured in an equilibrated $0.01 \mathrm{M} \mathrm{CaCl}_{2}$ solution (1:5 soil : liquid ratio). Mineral composition was measured by X-ray diffraction (XRD, CubiX ${ }^{3}$, Malvern Panalytical, Malvern, United Kingdom). Trace and major metals (e.g., $\mathrm{Fe}, \mathrm{Mn}, \mathrm{Cu}$ ) and total $\mathrm{Hg}(\mathrm{HgT})$ were extracted from soils using a $15.8 \mathrm{M}$ nitric acid microwave digestion and measured using an inductively coupled plasma mass spectrometer (ICP-MS, 7700x, Agilent Technologies, Santa Clara, United States of America). Methylmercury was selectively extracted with $\mathrm{HCl}$ and dichloromethane (DCM) using an adapted method described elsewhere (Gygax et al., 2019). We modified this method to achieve high throughput (64 samples per run) and measurements by high-pressure liquid chromatography (HPLC, 1200 Series, Agilent Technologies, Santa Clara, United States of America) coupled to the ICP-MS. Details on laboratory materials, extractions, analyt- ical methods and instrumentation are provided in the Supplement (Sects. S2, S3). The change in MeHg concentration in the microcosms was likely a result of the simultaneous production and degradation of $\mathrm{MeHg}$. Thus, the term "net $\mathrm{MeHg}$ production" was used to represent these processes. We calculated the relative net $\mathrm{MeHg}$ production during the incubation as the relative difference of $\mathrm{MeHg} / \mathrm{HgT}$ ratios between two time points $(t)$ using Eq. (1).

$\operatorname{Net~MeHg}$ production $(\%)=\frac{\left(\frac{\mathrm{MeHg}}{\mathrm{HgT}} t_{i-1}-\frac{\mathrm{MeHg}}{\mathrm{HgT}_{t}}\right)}{\frac{\mathrm{MeHg}}{\mathrm{HgT}} t_{i-1}} \times 100$

\subsection{Soil description}

Both soils were identified as Gleyic Fluvisols. They have a silt loam texture and the same mineral composition but differing $\mathrm{Hg}$ and organic carbon $\left(\mathrm{C}_{\mathrm{org}}\right)$ concentrations (Table 1). For elements relevant for $\mathrm{Hg}$ cycling, $\mathrm{Hg}$ molar ratios (HgT: $\mathrm{Cu}, \mathrm{HgT}: \mathrm{C}_{\text {org }}, \mathrm{HgT}: \mathrm{Mn}$ ) differ between samples and soils used in similar incubation experiments (Hofacker et al., 2013; Poulin et al., 2016). We note that the $\left[\mathrm{C}_{\text {org }} / \mathrm{Mn}\right]_{\text {molar }}$ was $30 \%$ higher in the LMHC soil compared to HMLC. Xray diffractograms of both soils is shown in Fig. S4. The soil diffractograms are overlapping each other, and the qualitative analyses of the diffractograms show that the soils' parental material is composed of the same five main mineral phases: quartz, albite, orthoclase, illite/muscovite and calcite.

\subsection{Soil solution sampling and analyses}

Soil solution was sampled $0.25,1,2,3,4,5,7,9,11$ and $14 \mathrm{~d}$ after the onset of each flooding period (Figs. 1, S5). It was sampled though the tubing connected to the suction cup $(<10 \mu \mathrm{m}$ pre size). The first $2 \mathrm{~mL}$ was sampled with a syringe and discarded to prime the system and condition the tubing. Then $4 \mathrm{~mL}$ was drawn through an airtight flowthrough system to measure the redox potential $(\mathrm{Hg} / \mathrm{HgCl}$ ORP electrode) and $\mathrm{pH}$. Then, approximately $35 \mathrm{~mL}$ of soil solution was sampled using a self-made syringe pump system allowing for a regular flow and minimal remobilization of fine particles. Like this, $4 \%-6 \%$ of the added artificial rainwater volume was sampled at each sampling point (Fig. S3). Throughout the experiment the soils remained entirely submerged. At each sampling time, sample splits were preserved without further filtration $(<10 \mu \mathrm{m})$ and filtered at $0.02 \mu \mathrm{m}$ (Whatman ${ }^{\circledR}$ Anodisc $0.02 \mu \mathrm{m}$, Sigma-Aldrich, St. Louis, United States of America). Additionally, at 2, 5 and $9 \mathrm{~d}$ an additional sample split was filtered at $0.45 \mu \mathrm{m}$ (Polytetrafluoroethylene Hydrophilic, BGB, Böckten, Switzerland) for colloid characterization. Incubation experiment blanks were taken by sampling Milli-Q water through from an empty $1 \mathrm{~L}$ borosilicate aspirator bottle three times throughout the experiment. Subsequently, the samples were subdivided and treated for different analyses. They were preserved in $1 \% \mathrm{HNO}_{3}$ for multi-elemental analysis $(\mathrm{Mn}, \mathrm{Fe}$, 


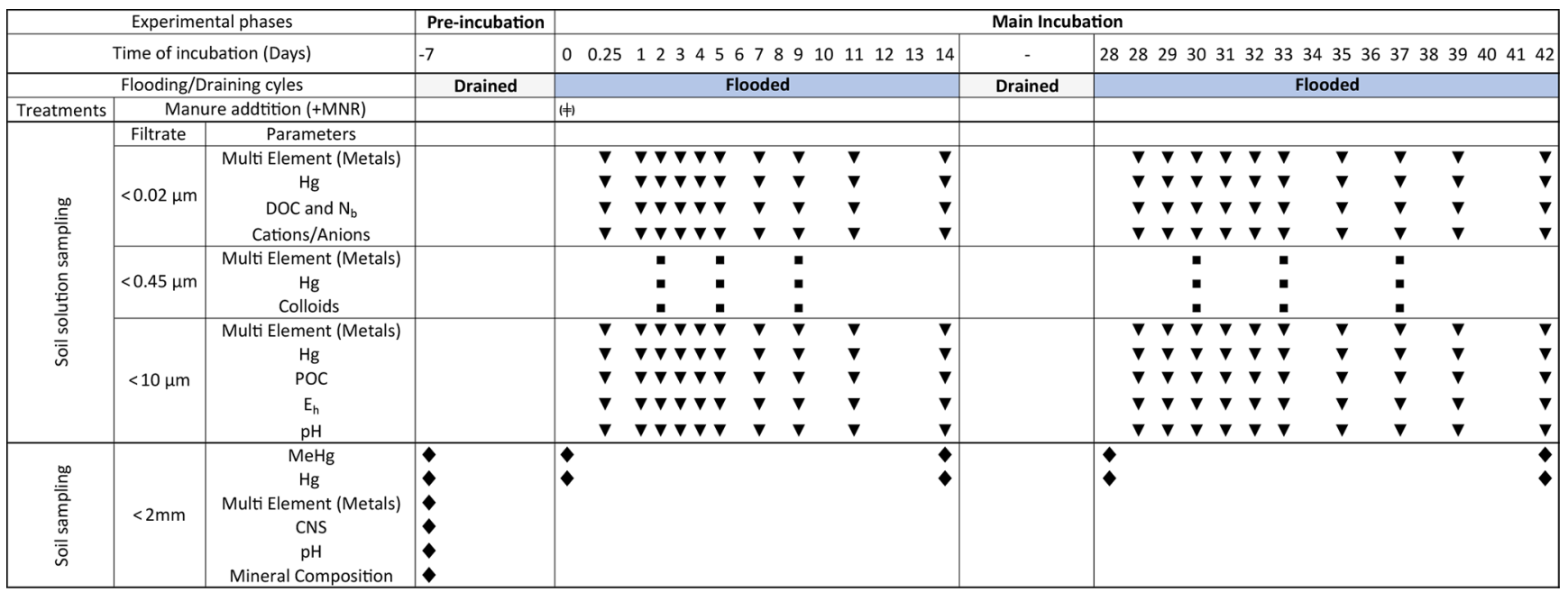

Figure 1. Schedule of preformed incubation experiment, samplings and measurements: blue bars indicate soil flooding periods. Gray bars represent drained periods. The width of the columns is not proportional to the time of incubation. In the treatments row the $(+)$ symbol indicates the addition of liquid manure to the microcosms specifically treated with manure $(+\mathrm{MNR})$. Triangles represent regular soil solution sampling points. Rectangles represent soil solution sampling for colloid analyses. Diamonds represent time points for soil sampling. At $-7 \mathrm{~d}$, soil was sampled from the pooled soil directly before the pre-incubation.

$\mathrm{Cu}, \mathrm{As})$ and in $1 \% \mathrm{HNO}_{3}$ and $0.5 \% \mathrm{HCl}$ for $\mathrm{HgT}$ analysis and analyzed by ICP-MS. For major anion $\left(\mathrm{Cl}^{-}, \mathrm{NO}_{3}^{-}\right.$, $\left.\mathrm{SO}_{4}^{2-}\right)$ and cation $\left(\mathrm{K}^{+}, \mathrm{Na}^{+}, \mathrm{Mg}^{2+}, \mathrm{Ca}^{2+}\right)$ measurements, samples were diluted $1: 4$ in ultra-pure water and analyzed by ion chromatography (Dionex Aquion ${ }^{\mathrm{TM}}$, Thermo Fisher Scientific Inc., Waltham, United States of America). Samples for dissolved organic carbon (DOC), particulate organic carbon $(\mathrm{POC})$ and total bound nitrogen $\left(\mathrm{TN}_{\mathrm{b}}\right)$ were diluted $1: 5$ and stabilized using $10 \mu \mathrm{L}$ of $10 \% \mathrm{HCl}$ and measured using an elemental analyzer (vario TOC cube, Elementar Analysensysteme, Langenselbold, Germany). Incubation experiment blanks were below $4.75 \mathrm{mg} \mathrm{L}^{-1}$ and $22.4 \mu \mathrm{g} \mathrm{L}^{-1}$ for $\mathrm{DOC}$ and $\mathrm{TN}_{\mathrm{b}}$, respectively. These relatively high blank values might originate from either the syringes or the suction cups (Siemens and Kaupenjohann, 2003). Uncertainties of soil solution parameters are displayed as $1 \mathrm{SD}$ of the triplicate incubation experiments throughout the paper. $\mathrm{HCO}_{3}^{-}$ concentrations were estimated based on the ionic charge balance of the soil solution using VisMinteq (https://vminteq. lwr.kth.se/, last access: 1 October 2020). A detailed schedule and list of analyses is provided in Fig. 1. Concentrations of specific filtered fractions are labeled with subscripts (e.g., $\mathrm{HgT}_{<0.02 \mu \mathrm{m}}$ ) for all measured metals. Particulate concentrations $(0.02 \mu \mathrm{m}<X<10 \mu \mathrm{m})$ (e.g., P-Fe) and their proportion to the total (e.g., $\mathrm{P}-\mathrm{Mn}_{\mathrm{rel}}$ ) were determined as the difference between unfiltered and filtered concentration (Table 2).

\subsection{Characterization of colloids (AF4)}

An aliquot of the soil solution was used for characterization of colloids in one out of three replicate microcosms (Rep1) of each treatment on days 2, 5 and 9 after the onset of each flooding period. Right after sampling, the aliquots were transferred to a $\mathrm{N}_{2}$ atmosphere in a glove box. There, the samples were filtered to $<0.45 \mu \mathrm{m}$ and preserved in airtight borosilicate headspace vials at $4{ }^{\circ} \mathrm{C}$. Colloidal size fractions and elemental concentrations of the filtrates were analyzed by asymmetrical flow field-flow fractionation (AF4, AF2000, Postnova Analytics, Landsberg am Lech, Germany) coupled to a $\mathrm{UV}_{254 \mathrm{~nm}}$ absorbance detector (UV, SPD-M20A, Shimadzu, Reinach, Switzerland), a fluorescence detector (FLD, RF-20A, Shimadzu, Reinach, Switzerland) and an ICP-MS (7700x, Agilent Technologies, Santa Clara, United States of America) within $14 \mathrm{~d}$ after sampling. Colloids contained in $1 \mathrm{~mL}$ of samples were separated in a channel made of a trapezoidal spacer of $350 \mu \mathrm{m}$ thickness and a regenerated cellulose membrane with a nominal cutoff of $1 \mathrm{kDa}$ used as the accumulation wall. The mobile phase used for AF4 elution was $10 \mathrm{mM} \mathrm{NH}_{4} \mathrm{NO}_{3}$ at $\mathrm{pH} 7$ and was degassed prior to entering the channel by argon flowing. A linear decrease in crossflow from 2 to $0 \mathrm{~mL} \mathrm{~min}^{-1}$ over $20 \mathrm{~min}$ was used after injecting the samples at an initial crossflow of $2.7 \mathrm{~mL} \mathrm{~min}^{-1}$. At the end of a run, the crossflow was kept at $0 \mathrm{~mL} \mathrm{~min}^{-1}$ for $5 \mathrm{~min}$ in order to elute non-fractionated particles. Retention times were transformed into hydrodynamic diameters $\left(d_{\mathrm{h}}\right)$ by an external calibration using Hemocyanin Type VIII from Limulus polyphemus hemolymph (monomer $d_{\mathrm{h}}=7 \mathrm{~nm}$, SigmaAldrich) and ultra-uniform gold nanoparticles (Nanocomposix) of known $d_{\mathrm{h}}(19$ and $39 \mathrm{~nm})$. Additionally, the elution of the smallest retention times $\left(d_{\mathrm{h}}<10 \mathrm{~nm}\right)$ was converted into molecular masses $(m)$ using polystyrene sulfonate standards (PSS) standards (Postnova analytic, Landsberg am Lech, Germany) with $m$ ranging from 1.1 to $64 \mathrm{kDa}$ (Fig. S6), using AF4-UVD $254 \mathrm{~nm}$. 
Table 1. List of soil parameters for the two incubated soils (HMLC and LMHC) and manure (MNR). Uncertainties are given as $1 \sigma$ standard deviation of triplicate experiments (method triplicates).

\begin{tabular}{|c|c|c|c|c|c|c|c|}
\hline \multicolumn{2}{|c|}{ Parameter } & \multicolumn{2}{|c|}{ Cornfield (HMLC) } & \multicolumn{2}{|c|}{ Pasture field (LMHC) } & \multicolumn{2}{|c|}{ Cow manure (MNR) } \\
\hline Land use & & Cornfield & & Pasture & & - & \\
\hline $\begin{array}{l}\text { Depth } \\
\text { Soil type (WRB) } \\
\text { pH } \\
\text { Water content }\end{array}$ & (wt \%) & $\begin{array}{r}0-20 \mathrm{~cm} \\
\text { Gleyic Fluvisol } \\
8.16 \\
13.8\end{array}$ & & $\begin{array}{r}0-20 \mathrm{~cm} \\
\text { Gleyic Fluvisol } \\
7.84 \\
8.5\end{array}$ & & $\begin{array}{r}- \\
- \\
- \\
90.3\end{array}$ & \\
\hline Water content & Unit (dry.wt.) & Concentration & SD & Concentration & SD & Concentration & $\mathrm{SD}$ \\
\hline $\mathrm{C}_{\text {org }}$ & wt $\%$ & 1.92 & 0.01 & 3.45 & 0.01 & 45.22 & 0.09 \\
\hline$N_{\text {tot }}$ & wt $\%$ & 0.181 & 0.001 & 0.372 & 0.002 & 3.68 & 0.08 \\
\hline $\mathrm{C}_{\text {org }} / N_{\text {tot }}$ & - & 10.61 & - & 9.29 & - & - & - \\
\hline$S$ & $\mathrm{~g} \mathrm{~kg}^{-1}$ & 0.63 & 0.05 & 0.77 & 0.05 & 3.7 & 0.1 \\
\hline $\mathrm{HgT}$ & $\mathrm{mg} \mathrm{kg}^{-1}$ & 47.3 & 0.5 & 2.4 & 0.3 & 0.045 & 0.001 \\
\hline $\mathrm{MeHg}$ & $\mu \mathrm{ggg}^{-1}$ & 26.9 & 0.2 & 6.4 & 0.2 & $<0.02$ & - \\
\hline $\mathrm{MeHg} / \mathrm{HgT}$ & $\%$ & 0.06 & - & 0.28 & - & - & - \\
\hline $\mathrm{Al}$ & wt $\%$ & 0.91 & 0.05 & 1.05 & 0.04 & 0.0106 & 0.0003 \\
\hline $\mathrm{Fe}$ & & 1.95 & 0.07 & 2.38 & 0.05 & 0.0336 & 0.0009 \\
\hline $\mathrm{Mg}$ & & 1.25 & 0.07 & 1.39 & 0.05 & 0.49 & 0.03 \\
\hline $\mathrm{Mn}$ & $\mathrm{mg} \mathrm{kg}^{-1}$ & 493 & 21 & 672 & 38 & 53 & 1 \\
\hline $\mathrm{P}$ & & 1169 & 80 & 1044 & 85 & 8245 & 232 \\
\hline $\mathrm{Cr}$ & & 56 & 4 & 64 & 5 & 0.68 & 0.01 \\
\hline $\mathrm{Co}$ & & 10.75 & 0.06 & 11.22 & 0.43 & 0.4 & 0.2 \\
\hline $\mathrm{Ni}$ & & 81.7 & 0.8 & 78.3 & 2.9 & 2.3 & 0.1 \\
\hline $\mathrm{Cu}$ & & 40.1 & 1.2 & 28.0 & 0.7 & 13.1 & 0.6 \\
\hline $\mathrm{Zn}$ & & 61.8 & 0.5 & 47.3 & 2.0 & 81 & 3 \\
\hline As & & 11.74 & 0.07 & 16.04 & 0.72 & 0.8 & 0.4 \\
\hline $\mathrm{Cd}$ & & 0.21 & 0.04 & 0.17 & 0.01 & 0.042 & 0.004 \\
\hline $\mathrm{Pb}$ & & 20.8 & 0.5 & 18.34 & 0.5 & - & - \\
\hline V & & 17.2 & 0.4 & 20.99 & 1.1 & 0.31 & 0.01 \\
\hline $\mathrm{Sr}$ & & 137 & 2 & 202 & 6 & 45.9 & 1.6 \\
\hline Cs & & 1.99 & 0.02 & 1.52 & 0.04 & - & - \\
\hline $\mathrm{Ba}$ & & 60.2 & 1.1 & 76.9 & 1.6 & 9.1 & 0.5 \\
\hline $\mathrm{Ce}$ & & 7.0 & 0.4 & 8.6 & 0.6 & - & - \\
\hline Gd & & 0.94 & 0.03 & 1.00 & 0.05 & 0.021 & 0.001 \\
\hline $\mathrm{U}$ & & 1.74 & 0.08 & 1.29 & 0.01 & 0.19 & 0.01 \\
\hline HgT / Cu molar & $\%$ & 366.3 & - & 25.73 & - & - & - \\
\hline HgT / Mn molar & & 25.758 & - & 0.926 & - & - & - \\
\hline $\mathrm{HgT} / \mathrm{C}_{\text {org }}$ molar & & 0.147 & - & 0.004 & - & - & - \\
\hline $\mathrm{Mn} / \mathrm{C}_{\text {org }}$ molar & & 0.0056 & - & 0.0042 & - & - & - \\
\hline
\end{tabular}

Fractograms obtained in counts per second (CPS) from time-resolved analysis (TRA) acquisition were converted to $\mu \mathrm{gL}^{-1}$ using external calibrations made from a multielement standard solution (ICP multi-element standard solution VI, Merk, Darmstadt, Germany) diluted in $1 \% \mathrm{HNO}_{3}$ or a $\mathrm{Hg}$ standard (ICP inorganic $\mathrm{Hg}$ standard solution, TraceCERT $^{\circledR}$, Sigma-Aldrich, St. Louis, United States of America) diluted in $1.0 \% \mathrm{HNO}_{3}$ and $0.5 \% \mathrm{HCl}$. The different size fractions were obtained by multiple extreme-shaped peak fitting, using OriginPro 2018 software (OriginLab Corporation). The peaks obtained were then integrated individually, after conversion of elution time to elution volume, to provide the quantity of $\mathrm{Hg}$ in each size fraction (Dublet et al., 2019). The analytes passing the $1 \mathrm{kDa}$ membrane are considered to be the $(<1 \mathrm{kDa})$ truly dissolved fraction. It was calculated by subtracting the concentrations of colloidal $\mathrm{HgT}$ recovered by AF4-ICP-MS (total integration of the $\mathrm{Hg}$ signals) to the total dissolved $\mathrm{HgT}$ concentrations measured separately by ICP-MS in corresponding acidified samples. The concentration of truly dissolved $\mathrm{Hg}$ is displayed as $\mathrm{HgT}_{<1 \mathrm{kDa}}$ for the rest of the article (Table 1). AF4-ICP-MS, $\mathrm{UV}_{254 \mathrm{~nm}}$ and fluorescence signals were used to further characterize Hg-bearing colloids, after hydrodynamic size separation by $\mathrm{AF} 4$. The $\mathrm{UV}_{254 \mathrm{~nm}}$ light absorption is widely used 
Table 2. Description of the symbols and terms used for different filter fractions in the publication. The particulate fraction is calculated as the difference of the $20 \mathrm{~nm}$ and the $10 \mu \mathrm{m}$ filtrate concentrations.

\begin{tabular}{|c|c|c|c|}
\hline Filter type & Filter size & Symbol (e.g., $\mathrm{HgT}_{x}$ ) & Description \\
\hline Suction cup & $10 \mu \mathrm{m}$ & $\mathrm{HgT}_{<10 \mu \mathrm{m}}$ & $\begin{array}{l}\text { Soil solution sampled directly from the suction cup contains a variety of par- } \\
\text { ticles (clay minerals, bacteria, } \mathrm{Mn} / \mathrm{Fe} \text { hydroxides, } \mathrm{POM} \text { aggregates, etc.). We } \\
\text { refer to this fraction by adding the subscripts }<10 \mu \mathrm{m} \text { to the analyte symbol. }\end{array}$ \\
\hline Syringe filter & $0.02 \mu \mathrm{m}$ & $\mathrm{HgT}_{<0.02 \mu \mathrm{m}}$ & $\begin{array}{l}\text { Soil solution }<0.02 \mu \mathrm{m} \text { is a cutoff size that may still carry colloids. We refer to } \\
\text { this fraction by adding the subscripts }<0.02 \mu \mathrm{m} \text { to the analyte symbol. }\end{array}$ \\
\hline- & - & $\mathrm{P}-\mathrm{HgT}$ & Particulate $\mathrm{Hg}$ is calculated as $\mathrm{P}-\mathrm{HgT}=\mathrm{HgT}_{<10 u m}-\mathrm{HgT}_{<0.02 u m}$ \\
\hline \multirow[t]{2}{*}{-} & - & $\mathrm{P}-\mathrm{HgT}_{\text {rel. }}$ & Relative particulate $\mathrm{HgT}$ is calculated as \\
\hline & & & $\mathrm{P}-\mathrm{HgT}_{\text {rel. }}=\left(\mathrm{HgT}_{<10 \mu \mathrm{m}}-\mathrm{HgT}_{<0.02 \mu \mathrm{m}}\right) / \mathrm{HgT}_{<10 \mu \mathrm{m}}$ \\
\hline AF4 membrane & $1 \mathrm{kDa}$ & $\mathrm{HgT}_{<1 \mathrm{kDa}}$ & $\begin{array}{l}\text { Molecules in solution under this cutoff size are not expected to have colloidal } \\
\text { properties. Therefore, this range is referred to as "truly dissolved" in the text. }\end{array}$ \\
\hline
\end{tabular}

to detect organic compounds, but it should be noted that part of the $\mathrm{UV}_{254 \mathrm{~nm}}$ light signal can also originate from $\mathrm{Fe}(\mathrm{II})$ or Fe hydroxides (Dublet et al., 2019). This was not the case in this study since $\mathrm{UV}_{254 \mathrm{~nm}}$ signals co-eluted with C signals recorded by ICP-MS and matched the fractograms obtained by the FLD detector tuned at the wavelengths specific for humic-like fluorophores. It is therefore assumed that the $\mathrm{UV}_{254 \mathrm{~nm}}$ signal represents organic compounds throughout the paper.

\section{Results}

\subsection{Soil solution chemistry and Hg dynamics}

In the HMLC microcosms, the $\mathrm{pH}$ of the soil solutions remained in a neutral-to-alkaline range of 8.0 to 8.4 during the incubation experiment (Fig. S7). Soil solution conditions and concentrations of constituents support a continuous reduction of soils with increased flooding time (Fig. 2a). Soil solution $\mathrm{NO}_{3}^{-}$depletion was observed during the first $7 \mathrm{~d}$ of incubation (Fig. 2b). Nitrate was under the detection limit for the second flooding phase. At day 7, Mn concentrations increased together with a marginal increase in Fe (Fig. 2c-f). This was coincided with a decrease in the relative particulate fraction $\left(\mathrm{P}-\mathrm{Mn}_{\text {rel. }}\right.$ and $\left.\mathrm{P}-\mathrm{Fe}_{\text {rell. }}\right)$ of these metals. Release of $\mathrm{Mn}$ and Fe was assumed to mark the onset of reductive dissolution of $\mathrm{Mn}$ and $\mathrm{Fe}$ oxyhydroxides. The decrease in sulfate $\left(\mathrm{SO}_{4}^{2-}\right)$ concentration could not be used to assess the onset of sulfate reduction. This is due to a chemical gradient between supernatant water and soil solution demonstrated by the continuous decrease in concentration of conservative ions $\mathrm{Cl}^{-}$, $\mathrm{Na}^{+}, \mathrm{K}^{+}$) (Sect. 4.4). To monitor sulfate reduction, we use the molar ratios of $\mathrm{SO}_{4}^{2-}$ to $\mathrm{Cl}^{-}$(Fig. 2g). Sulfate-to-chloride ratios stayed constant during the first flooding and slightly increased at the onset of the second flooding phase. This suggests that no sulfate reduction took place in the HMLC microcosms during the whole experiment. The DOC con- centration ranged between 37.5 and $106 \mathrm{mg} \mathrm{L}^{-1}$ (Fig. 2h). Both $\mathrm{HgT}_{<0.02 \mu \mathrm{m}}$ and $\mathrm{HgT}_{<10 \mu \mathrm{m}}$ concentrations remained low between days 0-5 (Phase 0), then increased together with the Mn release between days 5-11 (Phase 1) and decreased between days 14-29 (Phase 2) during the draining period (Fig. 3a). The relative fraction of particulate $\mathrm{HgT}$ (P$\mathrm{HgT}_{\text {rel. }}$ ) gradually decreased from a maximum of $88 \%$ to a minimum of $25 \%$ during phase 0 and phase 1 , but increased again to $60 \%-77 \%$ during phase 2 (Fig. $3 \mathrm{~b}-\mathrm{c}$ ). $\mathrm{Cu}_{<0.02 \mu \mathrm{m}}$ concentrations increased up to $88.2 \pm 17.5 \mu \mathrm{g} \mathrm{L}^{-1}$ within the first $4 \mathrm{~d}$ and then gradually decreased to $30.6 \pm 3.54 \mu \mathrm{g} \mathrm{L}^{-1}$ at day 14 (Fig. 4a). Arsenic concentrations simultaneously increased with the release of $\mathrm{Fe}$ during the whole incubation (Fig. 4b).

During the second flooding period, individual microcosms behaved differently in the HMLC run. The differences of soil solution $\mathrm{E}_{h}$ and redox-sensitive metals (e.g., Mn, Fe, $\mathrm{Hg}, \mathrm{Cu}$ ) were apparent from the start of the second flooding (Figs. 2c-f, 3a-c, 4a). Contrastingly, DOC concentrations and $\mathrm{pH}$ remained similar between incubators (Figs. 2h, S7). One replicate (Rep1) showed a pronounced increase in redox potential after the draining period (Fig. 2a). The $\mathrm{E}_{h}$ remained high $(150$ to $300 \mathrm{mV})$ for the whole second flooding period. A depletion and subsequent release of $\mathrm{Mn}$ in soil solution was observed, indicating the formation and redissolution of Mn oxyhydroxide minerals (Fig. 2c-d). Subsequently, $\mathrm{Mn}_{<0.02 \mu \mathrm{m}}$ increased and peaked at $448 \mu \mathrm{g} \mathrm{L}^{-1}$ by the end of the experiment in Rep1. The $E_{\mathrm{h}}$ of Rep2 was lower (between 28 and $120 \mathrm{mV}$ ), Mn concentrations did not decrease during the draining phase and a release of $\mathrm{Fe}$ was observed during the second flooding phase, indicating the reduction of Fe oxyhydroxides. Rep3 had a $E_{\mathrm{h}}$ in the range of Rep2 but neither a rerelease of $\mathrm{Mn}$ nor a release of $\mathrm{Fe}$ was observed during the second flooding phase. Also, HgT behaved differently within incubators during the second flooding period. Between days 29-42 (Phase 3), $\mathrm{HgT}_{<0.02 \mu \mathrm{m}}$ and $\mathrm{HgT}_{<10 \mu \mathrm{m}}$ concentrations increased or remained at higher levels for 
(a)
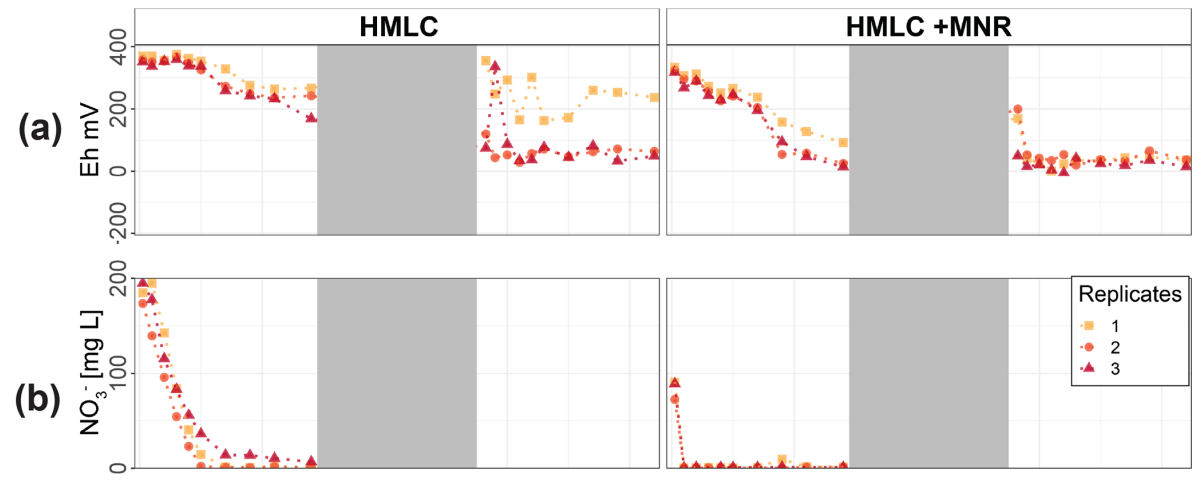

(c)
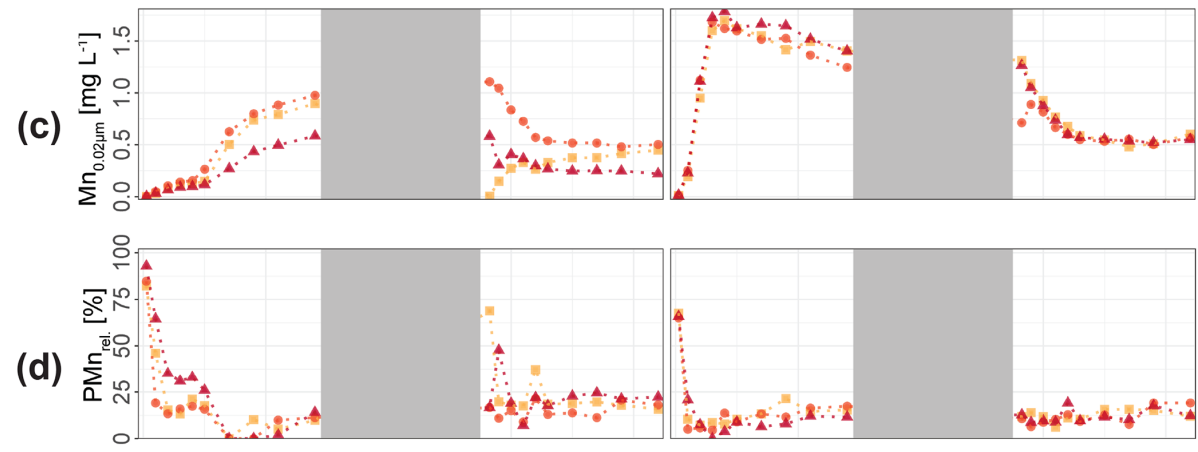

(e)

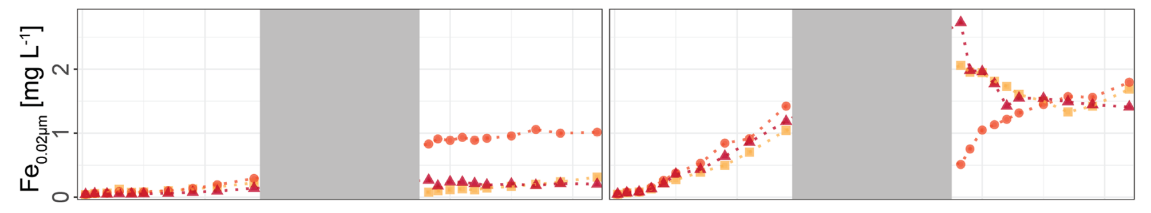

(f)

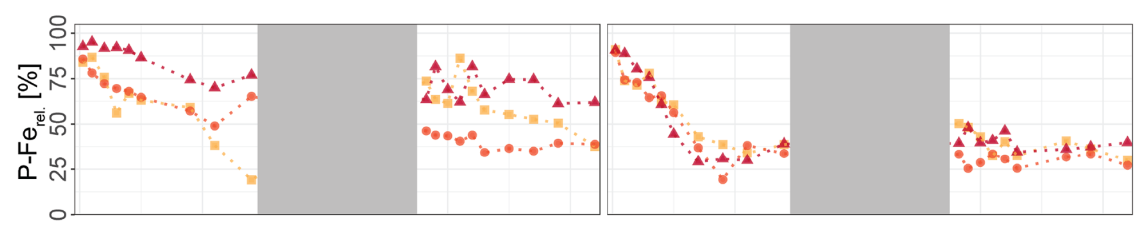

(g)

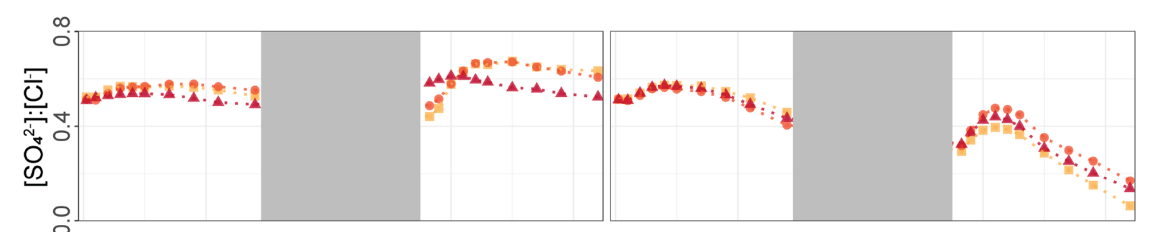

(h)

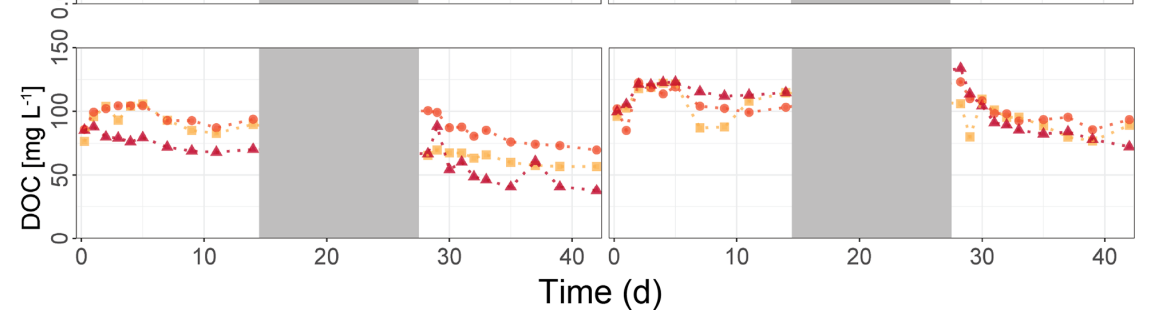

Figure 2. Soil solution dynamics in cornfield soil (HMLC) incubations for redox potential (a), redox reactive elements $\left(\mathrm{NO}_{3}^{-}\right.$, $\mathrm{Mn}, \mathrm{P}-\mathrm{Mn}$, $\left.\mathrm{Fe}, \mathrm{P}-\mathrm{Fe},\left[\mathrm{SO}_{4}^{2-}\right]:\left[\mathrm{Cl}^{-}\right]\right)(\mathbf{b}-\mathbf{g})$ and dissolved organic carbon $(\mathbf{h})$. Lines between points were plotted to improve readability. The gray area indicates the drained period. 

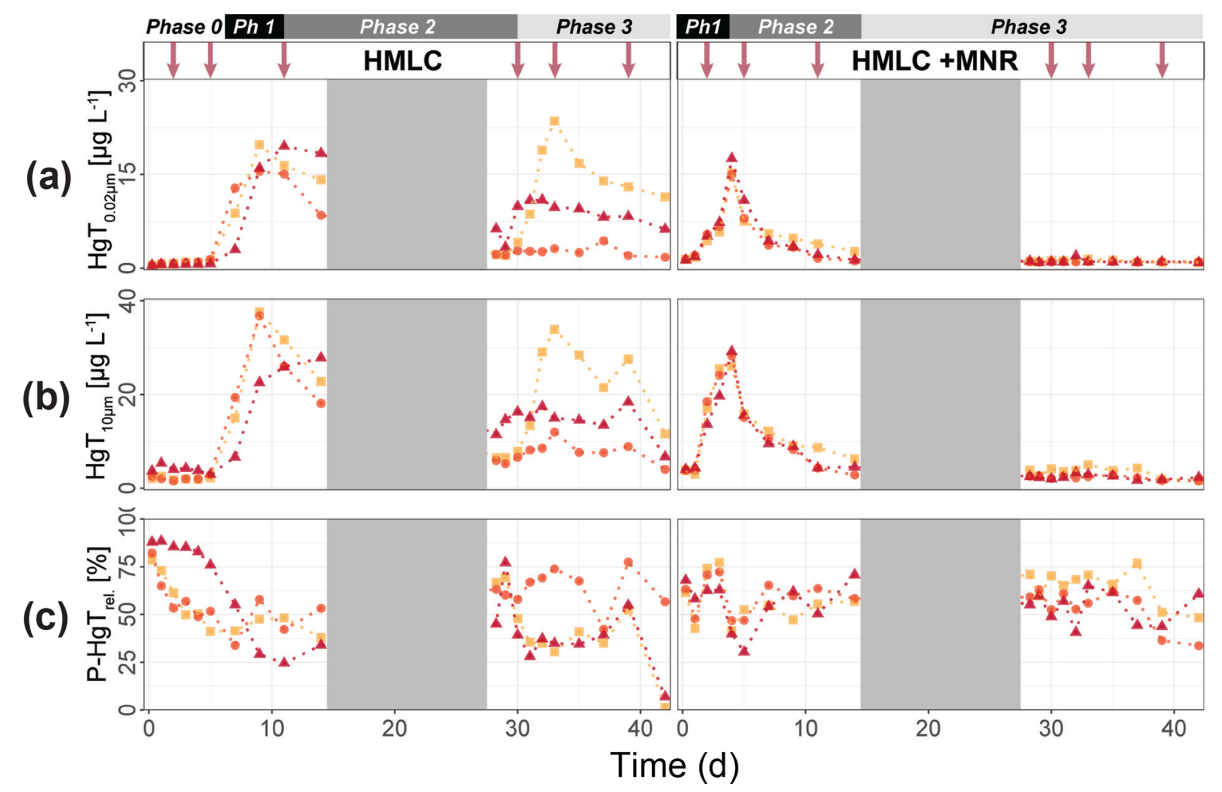

Figure 3. Soil solution dynamics in cornfield soil (HMLC) incubations for $\mathrm{Hg}$ (a-c) subdivided into phases (0-3). Lines between points were plotted to improve readability. The gray area indicates the drained period. Red arrows indicate sampling days for AF4-ICP-MS analyses.

(a)
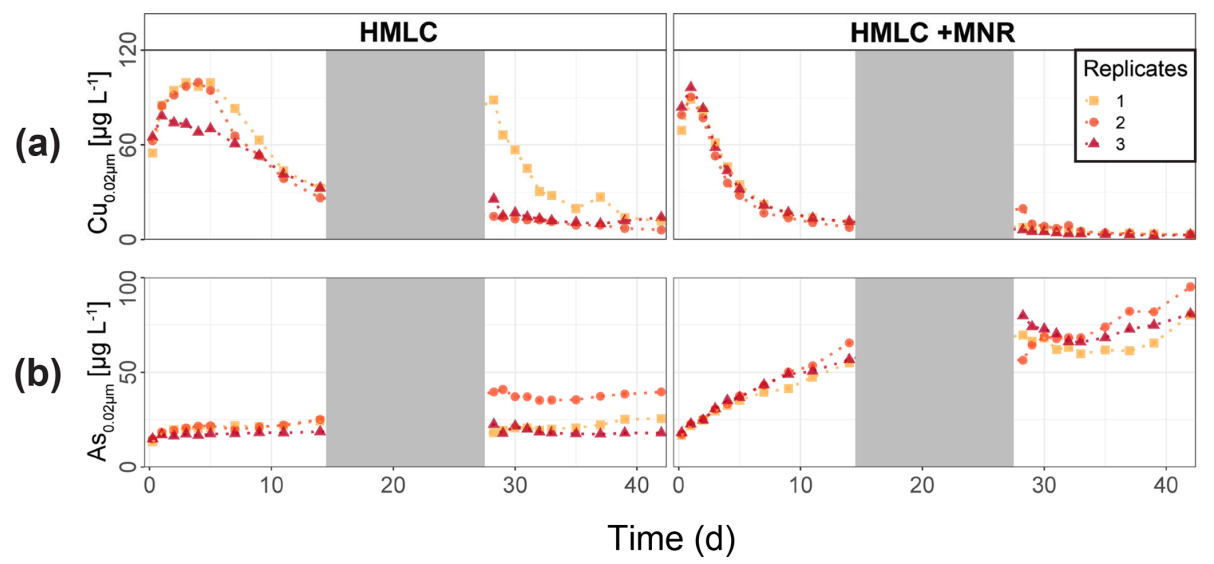

Figure 4. Soil solution dynamics in cornfield soil (HMLC) incubations for $\mathrm{Cu}$ (a) and As (b). Lines between points were plotted to improve readability. The gray area indicates the drained period.

Rep1 and Rep3. During this phase $\mathrm{P}-\mathrm{HgT}$ rel vastly decreased and was at a minimum of $1 \%-7 \%$ by the end of the incubation. Contrastingly, $\mathrm{HgT}_{<0.02 \mu \mathrm{m}}$ and $\mathrm{HgT}_{<10 \mu \mathrm{m}}$ stayed constantly low for Rep2 during phase 3, and P-HgT $\mathrm{T}_{\text {rel }}$ remained overall above $50 \%$. The Rep1 was the only MC that showed an increase in $\mathrm{Cu}$ concentrations during the draining phase (Fig. 4a).

In the HMLC + MNR microcosms, $\mathrm{pH}$ remained in the range of 8 to 8.35 with minor fluctuations over both flooding periods (Fig. S7). The redox potential decreased rapidly from approximately $E_{\mathrm{h}} 300 \mathrm{mV}$ to $5.27 \pm 14.4 \mathrm{mV}$ within the first $14 \mathrm{~d}$ and remained constant at $14.3 \pm 8.12 \mathrm{mV}$ during the second flooding period. Depletion of $\mathrm{NO}_{3}^{-}$was observed within the first day of incubation and was under the detection limit during the second flooding period (Fig. 2b). A rapid release of Mn started at day 2, and a slow release of $\mathrm{Fe}$ started at day 3 of the first flooding period (Fig. 2cf). The $\left[\mathrm{SO}_{4}^{2-}\right]:\left[\mathrm{Cl}^{-}\right]$ratios decreased from $0.57 \pm 0.01$ to $0.37 \pm 0.02$ between days 4-29. During the second flooding period $\left[\mathrm{SO}_{4}^{2-}\right]:\left[\mathrm{Cl}^{-}\right]$ratios initially increased slightly between days 29-31 and then decreased to a minimum $(0.12 \pm 0.05)$ by the end of the incubation (Fig. $2 \mathrm{~g}$ ). DOC concentrations were between 72.2 and $134 \mathrm{mg} \mathrm{L}^{-1}$ (Fig. 2h). This was significantly higher ( 3 to $43 \mathrm{mg} \mathrm{L}^{-1}$ ) than in HMLC without manure. In these microcosms $\mathrm{HgT}_{<0.02 \mu \mathrm{m}}$ and $\mathrm{HgT}_{<10 \mu \mathrm{m}}$ concentrations instantly increased together with the Mn release between days 0-4 (phase 1), decreased during days 5-14 (phase 2) and remained low between days 
14-42 (phase 3) (Fig. 3a-c). The particulate $\mathrm{HgT}\left(\mathrm{P}-\mathrm{HgT}_{\text {rel. }}\right.$ ) decreased to $30 \%-52.5 \%$ in phase 1 and remained overall above $50 \%$ for the rest of the incubation. At the onset of phase 2 black precipitates were visually observed in the HMLC + MNR microcosms (Fig. S13). Cu concentrations decreased gradually during the course of the incubation experiment (Fig. 4a). Arsenic concentrations simultaneously increased with the release of $\mathrm{Fe}$ during the whole incubation (Fig. 4b).

LMHC differed from HMLC in soil solution chemistry. In both treatments (LMHC and LMHC + MNR), $\mathrm{pH}$ remained neutral but gradually decreased from 8.2 to 7.5 during the incubation (Fig. S7). Soil reduction progressed rapidly from a $\max$ of $332 \mathrm{mV}$ at day 3 to $-14.3 \mathrm{mV}$ at day 14 (Fig. 5a). During the second flooding $E_{\mathrm{h}}$ stayed in the range of -2.3 to $34.5 \mathrm{mV}$. Nitrate was exhausted within the first day of incubation and marked the onset of $\mathrm{Mn}$ release. $\mathrm{Mn}$ as well as DOC concentrations gradually increased during the first flooding period (Fig. 5b-c). Fe release started on day 4 and day 6 in LMHC and LMHC + MNR (Fig. 5d). A decrease in $\left[\mathrm{SO}_{4}^{2-}\right]:\left[\mathrm{Cl}^{-}\right]$ratio was observed after day 5 and remained stable at $0.03 \pm 0.04$ during the second flooding period. This is indicative of sulfate reduction during the draining phase and the second flooding phase (Fig. 5e). Soil solution $\mathrm{HgT}_{<0.02 \mu \mathrm{m}}$ concentration $\left(25-160 \mathrm{ng} \mathrm{L}^{-1}\right.$ ) was 2 orders of magnitude lower than in the HMLC runs (Figs. 2, 3a, 6a). Dissolved $\mathrm{HgT}_{<0.02 \mu \mathrm{m}}$ degreased during the first flooding period (phase 1), increased during the draining period (phase 2) and gradually decreased again during the second flooding period (phase 3) (Fig. 6a-c). No other soil solution parameter followed the trend of $\mathrm{HgT}_{<0.02 \mu \mathrm{m}}$. Particulate $\mathrm{HgT}_{<10 \mu \mathrm{m}}$ decreased during phase 1 and remained low during phases 2 and 3. In the $\mathrm{LMHC}$ microcosms $\mathrm{P}-\mathrm{HgT}_{\text {rel. }}$. changed drastically between phase $1(>65 \%)$ and phase 3 $(\ll 50 \%)$ (Fig. 3c). In the LMHC + MNR microcosms the $\mathrm{P}-\mathrm{HgT}_{\text {rel. }}$ was high during phase $1(>65 \%)$ and fluctuated in phase $3(\ll 50 \%)$ (Fig. 3c). Cu concentrations gradually decreased during the course of the experiment (Fig. 7a). Arsenic concentrations simultaneously increased with the release of Fe during the whole incubation (Fig. 7b).

\subsection{Colloidal Hg (AF4)}

Hg-bearing colloids were detected in all soil solution samples of HMLC incubations. Due to low signal-to-noise ratios $(<3)$, we did not detect colloidal $\mathrm{Hg}$ in samples of the LMHC incubations. Figure 8 shows the evolution of concentrations and relative proportions of $\mathrm{HgT}$ size fractions. Generally, changes in proportions were apparent during phases of $\mathrm{Hg}$ release and decrease in soil solution, but little change was observed when $\mathrm{Hg}$ concentrations were stagnant (HMLC + MNR, phase 3 ). The proportion of truly dissolved $\mathrm{HgT}_{<1 \mathrm{kDa}}$ varied between $0 \%$ and $67 \%$ in the HMLC experiment and was high during $\mathrm{Hg}$ release to soil solution (phases 1 and 3) (Fig. 8). In the HMLC + MNR treat- ment, $\mathrm{HgT}_{<1 \mathrm{kDa}}$ values were lower and ranged between $0 \%$ and $29 \%$. The colloidal $\mathrm{Hg}$ can be divided into three main fractions (Fig. 9). The first $\mathrm{Hg}$ colloidal fraction showed a main peak ranging between $1-40 \mathrm{kDa}\left(d_{\mathrm{h}}<6 \mathrm{~nm}\right)$ and was associated with $\mathrm{UV}_{254} \mathrm{~nm}$-absorbing compounds and various metals ( $\mathrm{Mn}, \mathrm{Fe}, \mathrm{Cu}, \mathrm{Ni}, \mathrm{Zn}$ ). This fraction was interpreted as humic substance type $\mathrm{Hg}-\mathrm{NOM}$. The proportion of this colloidal $\mathrm{Hg}$ fraction varied with no specific trends from $11.5 \%$ to $23.3 \%$ in HMLC and $13.6 \%$ to $38.6 \%$ in HMLC+ MNR throughout the course of the experiment. A second fraction of $\mathrm{Hg}$ colloids ranged between 6 and $20 \mathrm{~nm}$. This welldefined size fraction was eluting in the tail of the first fraction for other metals (e.g., $\mathrm{Fe}, \mathrm{Mn}, \mathrm{Cu}$ ) but did not overlap with $\mathrm{UV}_{254 \mathrm{~nm}}$ and fluorescence signals (Fig. 9). This fraction could not be chemically defined but is hypothesized to consist of $\beta-\mathrm{HgS}_{(\mathrm{s})}$ colloids. In the HMLC run, we observed a decrease in the proportion of these inorganic colloids from $28 \%$ in phase 0 to $15.3 \%$ at the end phase 3 (Fig. 9). In the HMLC + MNR treatment, the proportion of this fraction ranged between $29.5 \%$ and $41.9 \%$ during phases 1 and 2 and could not be detected during phase 3 . Further, we observed a third colloidal fraction that continued to elute after the stop of the AF4 crossflow, and it included colloids in the range of 30-450 $\mathrm{nm}$ (effective cutoff of the filter used for the sample preparation). In some cases, this fraction was better fitted using two overlapping populations (Figs. 9, S9S12). In all the cases, HgT signal was associated with those of other metals and a slight bump of the $\mathrm{UV}_{254 \mathrm{~nm}}$ signal but more specifically an increase in fluorescence signal associated with protein-like fluorophores. This fraction decreased continuously in the HMLC runs during the incubation from $32.4 \%$ in phase 2 to $5.6 \%$ in phase 2 and remained under $9.1 \%$ during phase 3 . By contrast, the HMLC + MNR showed an increase in the proportion of this fraction from $7.3 \%$ in phase 1 to $25.3 \%$ by the end of phase 3 (Fig. 8). The deconvolution of the fractograms included an intermediate fraction of $\mathrm{Hg}$-bearing colloids ranging between $d_{\mathrm{h}}=6 \mathrm{~nm}$ and $d_{\mathrm{h}}=450 \mathrm{~nm}$ depending on the sample. This fraction was added to refine the fractogram fittings but could not directly be associated with another measured metal. This indicates that this population represents a polydispersed $\mathrm{Hg}$ particle population, although in some cases the presence of small $\mathrm{Hg}$ particles dominates. This broad fraction was not detected in HMLC + MRN treatments during phases 1 and 2 but made up $>30 \%$ during phase 3 .

\subsection{Net MeHg production in soil}

Soil MeHg levels fluctuated over the course of the incubation experiment (Fig. 10 and Table 2). The highest net MeHg production was observed during the first flooding period for the treatments with manure (up to $+81 \%$ ) and during the draining phase for the treatments without manure (up to $+73.1 \%$ ). We observed a significant decrease in $\mathrm{MeHg}$ / $\mathrm{HgT}$ and absolute $\mathrm{MeHg}$ concentrations in all incubators during the second 
(a)

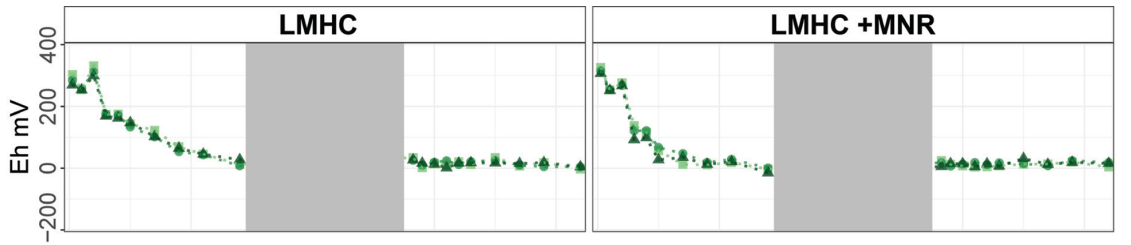

(b)

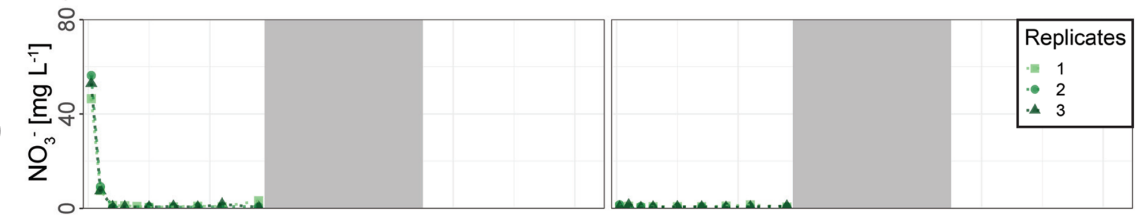

(c)

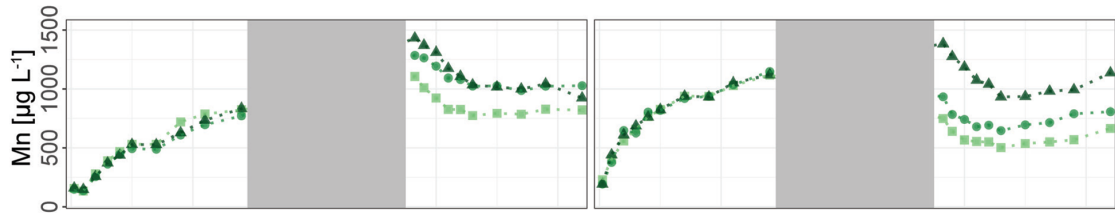

(d)

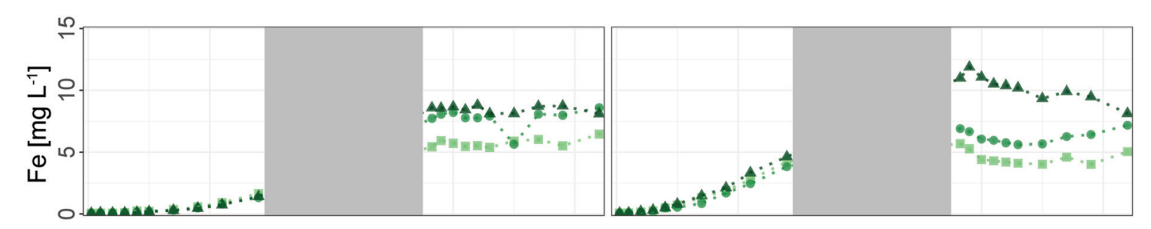

(e)

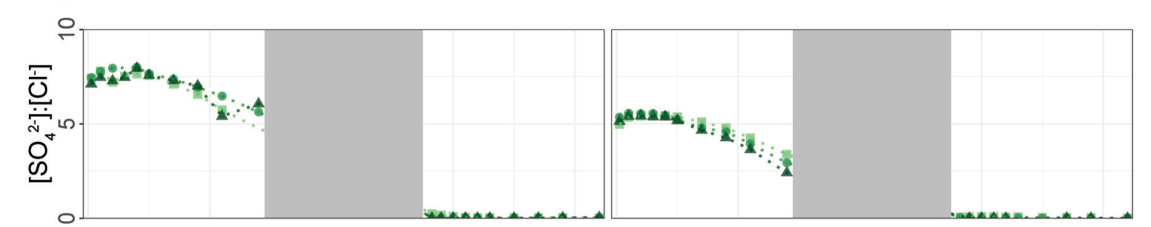

(f)

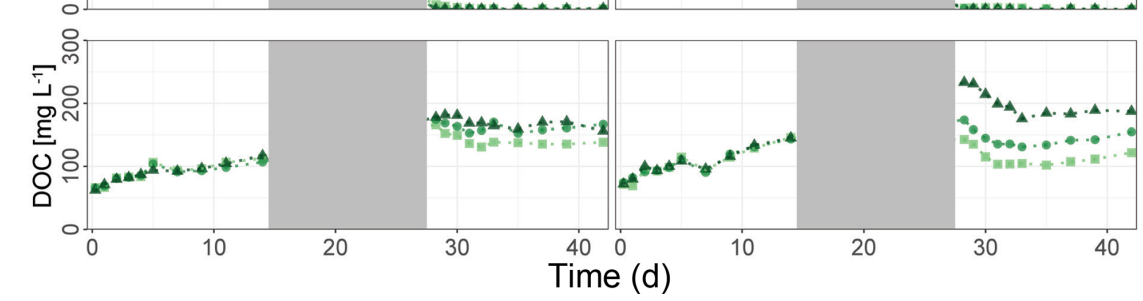

Figure 5. Soil solution dynamics in pasture field soil (LMHC) incubations for redox potential (a), redox-reactive elements $\left(\mathrm{NO}_{3}^{-}, \mathrm{Mn}, \mathrm{P}-\mathrm{Mn}\right.$, $\left.\mathrm{Fe}, \mathrm{P}-\mathrm{Fe},\left[\mathrm{SO}_{4}^{2-}\right]:\left[\mathrm{Cl}^{-}\right]\right)(\mathbf{b}-\mathbf{e})$ and dissolved organic carbon (f). Lines between points were plotted to improve readability. The gray area indicates the drained period.

flooding period (Fig. 10). In all microcosms, $\mathrm{MeHg} / \mathrm{HgT}$ increased by a factor of 1.18 to 1.36 throughout the incubation (Table 2).

\section{Discussion}

\subsection{Mercury release and sequestration}

Cornfield soil (HMLC) and pasture field soil (LMHC) behaved differently in this incubation experiment and will be discussed separately. In the cornfield soil (HMLC) $\mathrm{Hg}$ and $\mathrm{Mn}$ releases were simultaneous and started when soil solution $E_{\mathrm{h}}$ entered the field of $\mathrm{Mn}$ reduction below approximately $300 \mathrm{mV}$ (Figs. 2c, 3a), strongly sug- gesting that this $\mathrm{Hg}$ pool was released by reductive dissolution of Mn oxyhydroxides. During all experiments, low $\mathrm{Hg}$ : DOM ratios $\left(\ll 1 \mathrm{nmol} \mathrm{Hg}(\mathrm{mg} \mathrm{DOM})^{-1}\right)$ suggest that strong binding sites of DOM were never saturated with respect to mercury, assuming a binding site $\left[\mathrm{RS}_{2}^{2-}\right]$ density of $5 \mathrm{nmol} \mathrm{Hg}(\mathrm{mg} \mathrm{DOM})^{-1}$ and that DOC is $50 \%$ of the DOM (Haitzer et al., 2002). The low $\mathrm{Hg}$ : DOM ratio suggests that $\mathrm{Hg}$ is mainly present as complexed with DOM given reported strong interaction with thiol sites of DOM. However, these assumptions might not reflect the actual composition of DOM, which might drastically differ in amended soils (Li et al., 2019). Reductive dissolution of Mn oxyhydroxides drives both (1) the release of labile $\mathrm{Hg}-\mathrm{NOM}$ complexes and $\mathrm{Hg}^{2+}$ sorbed on the oxide's surfaces and/or (2) enhanced the degradation and mineralization of unsubtle NOM binding $\mathrm{Hg}$ 


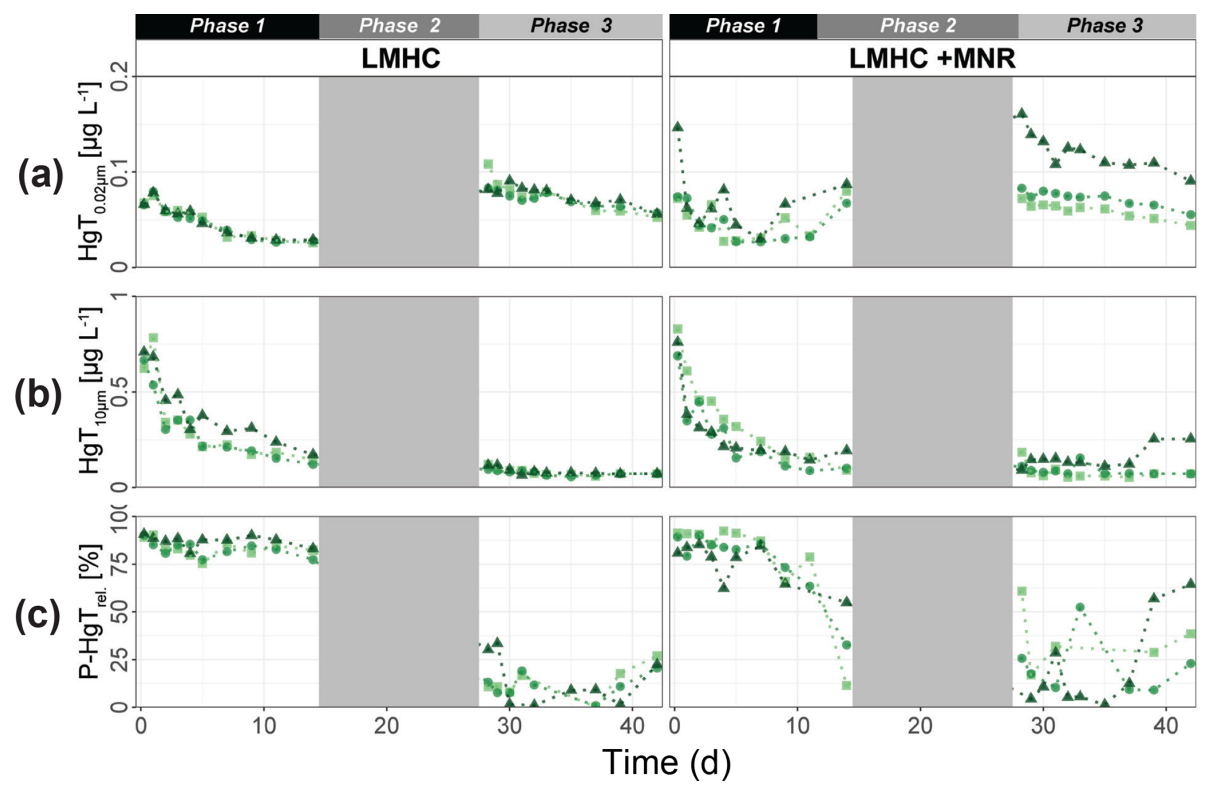

Figure 6. Soil solution dynamics in pasture field soil (LMHC) incubations for $\mathrm{Hg}$ (a-c) subdivided into phases (1-3). Lines between points were plotted to improve readability. The gray area indicates the drained period.

(a)

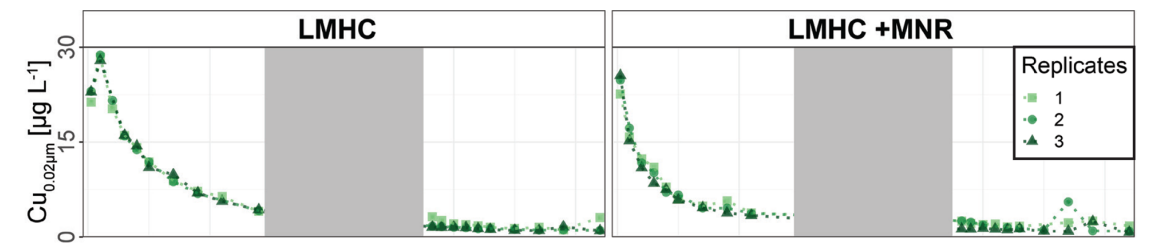

(b)

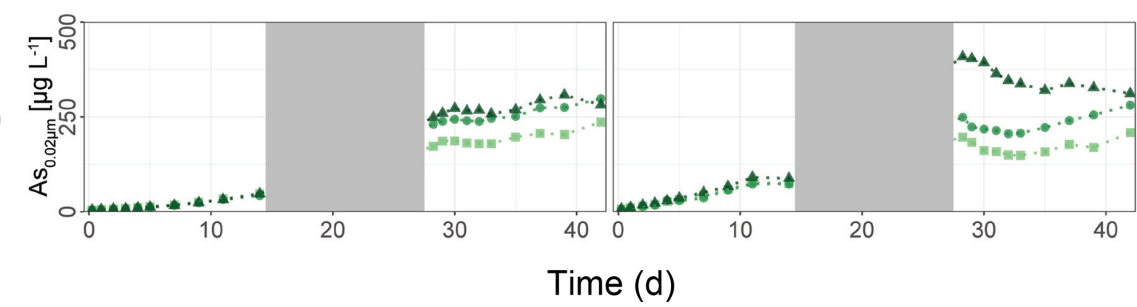

Figure 7. Soil solution dynamics in pasture field soil (LMHC) incubations for $\mathrm{Cu}$ (a) and As (b). Lines between points were plotted to improve readability. The gray area indicates the drained period.

in soils (Jones et al., 2018). After $\mathrm{Hg}$ release (phase 1), $\mathrm{Hg}$ concentrations remained high, and the relative particulate $\mathrm{Hg}$ fraction was low throughout the experiment. This illustrates that the released $\mathrm{Hg}$ pool mainly originated from Mn oxyhydroxides or degradation of suspended POM during Mn reduction. However, the released $\mathrm{Hg}$ pool is relatively small compared to the HgT levels of the soil. We estimate that about $12.8 \pm 4.2 \mu \mathrm{g} \mathrm{kg}^{-1} \mathrm{Hg}\left(0.02 \%\right.$ of $\left.\mathrm{HgT}_{\text {soil }}\right)$ was evacuated by sampling during the experiment. In this Fluvisol, $\mathrm{Hg}$ mobilization is thus mainly driven by reductive dissolution of Mn oxyhydroxides. Direct mobilization of DOM was reported to govern $\mathrm{Hg}$ levels in peat soils, Histosols or Podsols in boreal environments (Åkerblom et al., 2008; Kronberg et al., 2016; Jiskra et al., 2017), or floodplain soils with higher
OC levels (Beckers et al., 2019; Wang et al., 2021) in temperate soils.

Further, $\mathrm{Hg}$ mobilization was not simultaneous to $\mathrm{Cu}$ release. This was reported for polluted soils with high $\mathrm{Cu}$ levels (Hofacker et al., 2013) and a comparably low $\mathrm{Hg} / \mathrm{Cu}_{\text {molar }}$ ratio in the soil matrix. In neighboring soils, the main $\mathrm{Hg}$ pool was previously reported as $\mathrm{HgS}_{(\mathrm{s})}$ and $\mathrm{Hg}$ complexed by recalcitrant NOM (Grigg et al., 2018). Earlier studies assumed that $0.1 \%$ to $0.6 \%(w / w)$ of NOM was reduced sulfur with a high affinity to $\mathrm{Hg}$ (Grigg et al., 2018; Ravichandran, 2004). Following this assumption, reduced sulfur groups of the cornfield soil NOM could sorb between 11.9 and $71.9 \mathrm{mg} \mathrm{kg}^{-1}$ of $\mathrm{Hg}$. The soils' high $\mathrm{Hg}$ concentration $\left(47.3 \pm 0.5 \mathrm{mg} \mathrm{kg}^{-1}\right)$ suggests that soil NOM thiol 


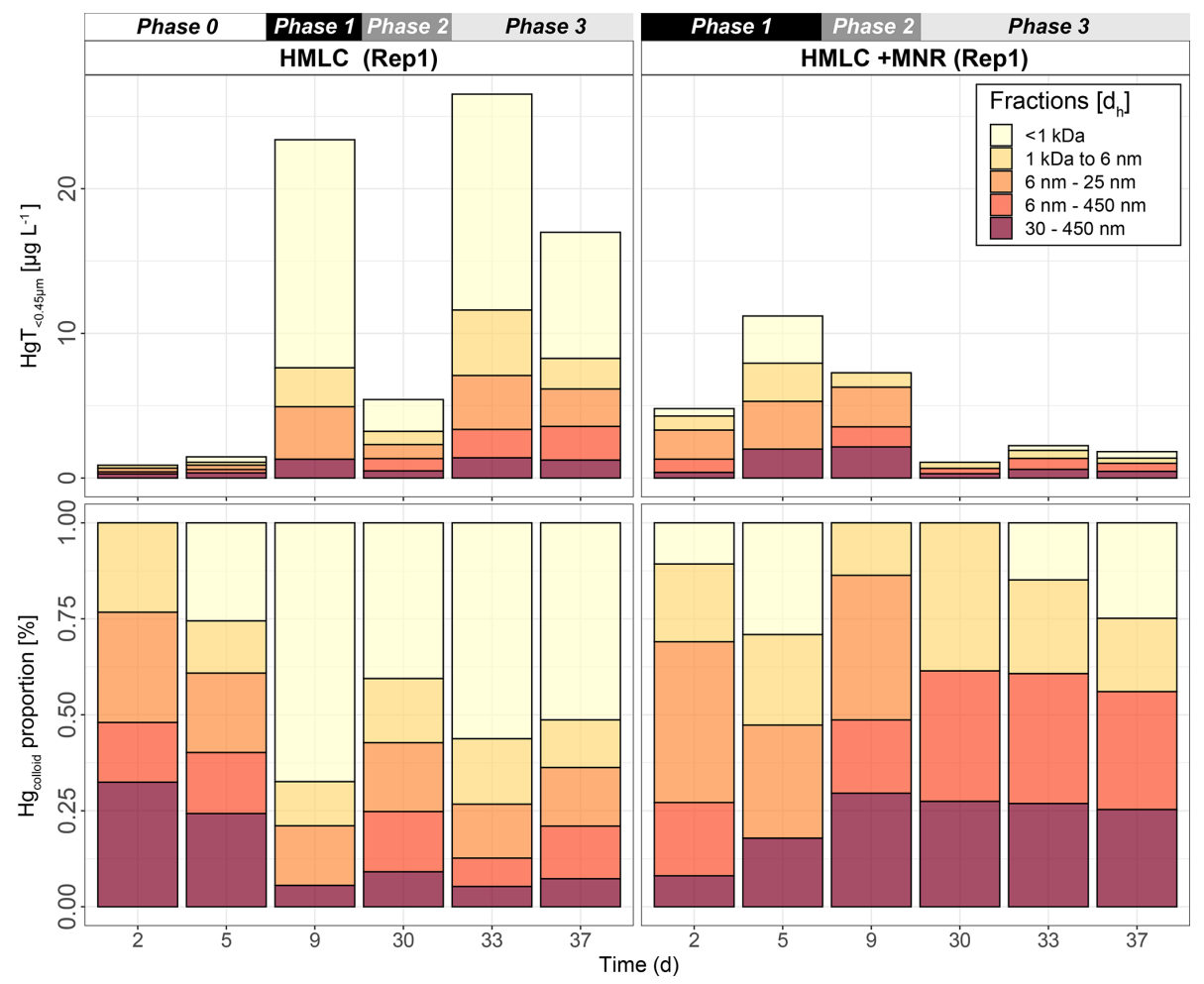

Figure 8. Size distribution of $\mathrm{Hg}$ estimated after AF4 fractogram deconvolution for Rep1 of cornfield soil incubation (HMLC and HMLC + MNR) subdivided into phases (0-3). The concentration of HgT in size fractions was calculated using an external calibration of the ICP-MS directly after the AF4 run. The concentration of $\mathrm{HgT}$ in " $<1 \mathrm{kDa}$ " was calculated by subtracting the sum of the fractions from the $\mathrm{HgT}$ concentration in the same sample measured separately by ICP-MS. The fractograms of all analyzed time points are shown in the Supplement (Figs. S9-S12).

sites are likely saturated in terms of $\mathrm{Hg}$. Therefore, saturated NOM sorption sites do not compete with Mn oxyhydroxide sorption sites, resulting in a substantial Mn-oxyhydroxidebound $\mathrm{Hg}$ pool. This leads to a higher mobility of $\mathrm{Hg}$ upon reductive dissolution of $\mathrm{Mn}$ oxyhydroxide compared to Fluvisols used in other incubation studies (Hofacker et al., 2013; Poulin et al., 2016; Beckers et al., 2019).

During the second flooding phase, the cornfield soil (HMLC) runs showed a higher variability in redox-sensitive soil solution parameters (Fig. 2). This might be explained as (1) a shift in microbial communities, (2) disturbance of the soil column by invasive soil sampling in between the flooding periods or (3) uneven draining of the pore space after the first flooding. It can also reflect how the redox cycle can be easily affected in situ. We suggest that the second release of $\mathrm{Mn}$ and $\mathrm{Hg}$ in Rep1 is due to Mn re-oxidation during the draining period and a second reductive dissolution of Mn oxyhydroxides upon reflooding. This is supported by the elevated $E_{\mathrm{h}}$ at the onset of the second flooding. Further, Mn reduction oxidation and reduction cycles were shown to enhance the degradation of NOM to more labile forms (Jones et al., 2018), which might contribute to the degradation/mineralization of recalcitrant Hg-NOM. The HMLC Rep3 showed a second release of $\mathrm{Hg}$ without a remobilization of $\mathrm{Mn}$. Changing re- dox conditions have been shown to enhance microbial respiration and therefore NOM degradation (Sunda and Kieber, 1994). Thus, we interpret the second $\mathrm{Hg}$ release in Rep3 as a degradation/mineralization of NOM that bound $\mathrm{Hg}$.

The carbon amendments were reported to decrease total $\mathrm{Hg}$ release in polluted floodplain soils (Beckers et al., 2019) but may have a mobilizing effect in NOM-depleted environments (Eckley et al., 2021). The addition of manure accelerated the release of $\mathrm{Hg}$ through reductive dissolution of $\mathrm{Mn}$ oxyhydroxides in the cornfield soil (HMLC). Mercury was released $4 \mathrm{~d}$ earlier, as a result of additional labile carbon of the liquid manure (1) acting as an electron donor enhancing microbial soil reduction (Liu et al., 2020) and (2) acting directly as a reductant of the Mn oxyhydroxides (Remucal and Ginder-Vogel, 2014). In the manure treatment, we observed a fast decrease in $\mathrm{Hg}$ concentration and a constantly high proportion of particulate $\mathrm{P}-\mathrm{HgT}_{\text {rel. }}$ even after the plateau of $\mathrm{Mn}$ concentration in soil solution and the relative decrease in particulate Mn. The addition of manure acts as a source of POM (manure was sieved to $<500 \mu \mathrm{m}$ ) and increased DOC by approximately $20 \mathrm{mg} \mathrm{L}^{-1}$. Sorption of $\mathrm{Hg}$ is directed towards thiol rich high-molecular-weight NOM (Liang et al., 2019) following different ligand exchange reactions (e.g., carboxyl groups to thiol groups) which happen within days (Miller 


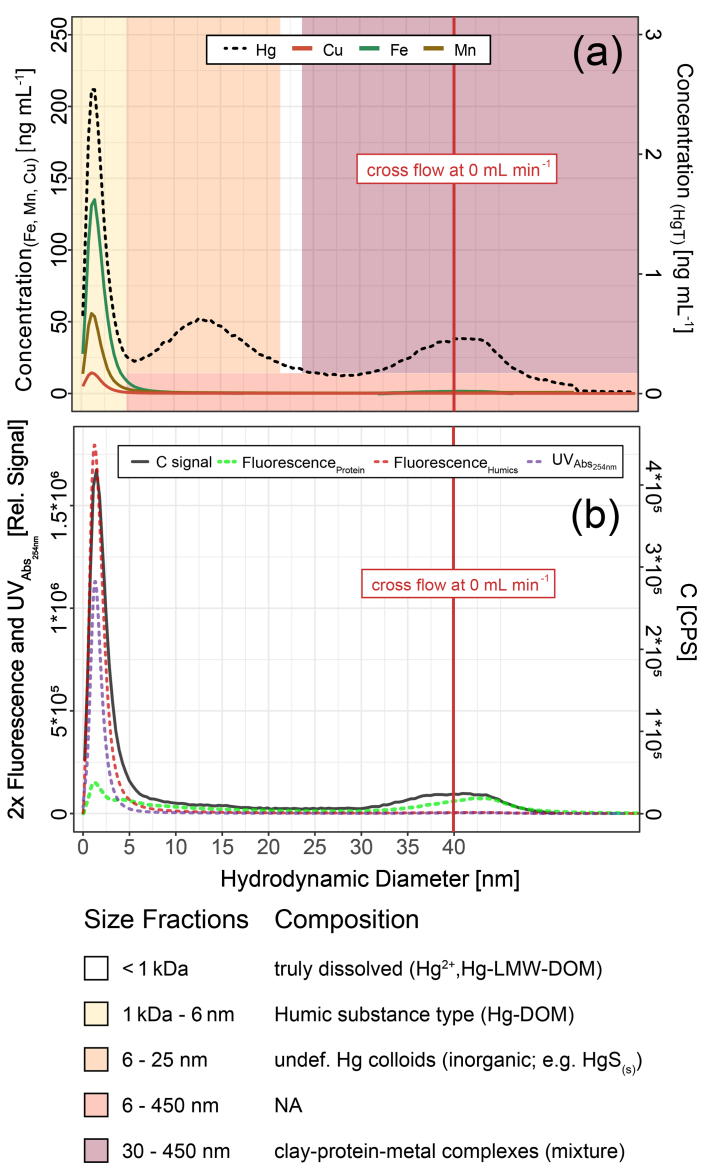

Figure 9. $\mathrm{Hg}, \mathrm{Cu}, \mathrm{Mn}$ and $\mathrm{Fe}$ concentrations (a) and $\mathrm{C}$ signals (ICPMS) and UV254nm absorbance and fluorescence signals (b) in colloids as a function of hydrodynamic diameter (related to retention times on AF4) in a sample from HMLC at day 9 after flooding. These fractograms were obtained at linearly decreasing crossflow from 2 to $0 \mathrm{~mL} \mathrm{~min}^{-1}$ over $20 \mathrm{~min}$. The red line indicates the time point where the crossflow reached $0 \mathrm{~mL} \mathrm{~min}^{-1}$. Areas (yellow to red color) indicate size fraction ranges assigned during deconvolution.

et al., 2009; Chiasson-Gould et al., 2014). The constant of $\mathrm{P}-\mathrm{Hg}_{\text {rel }}$ proportion is suggested to be partly caused by the complexation of dissolved $\mathrm{Hg}$ with the added POM of the manure.

In addition, we visually observed black precipitates (Fig. S13) and the decrease in $\left[\mathrm{SO}_{4}^{2-}\right]:\left[\mathrm{Cl}^{-}\right]$ratios (Fig. $2 \mathrm{~g}$ ) at the onset of $\mathrm{Hg}$ decrease (phase 2) in the microcosms with manure addition. This indicates the precipitation of sulfide mineral particles. Although redox potential measurements did not indicate sulfate reduction, the monitoring of $E_{\mathrm{h}}$ in soil solution provides only a qualitative measure in a complex soil system. We suggest that formation and aggregation of $\beta-\mathrm{HgS}_{(\mathrm{s})}$ explain the faster decrease in the manure-amended experiment. Furthermore, formation of metacinnabar $\beta-\mathrm{HgS}_{(\mathrm{s})}$ was observed under oxic conditions by conversion of thiol-bound $\mathrm{Hg}(\mathrm{SR})_{2}$ (Manceau et al.,
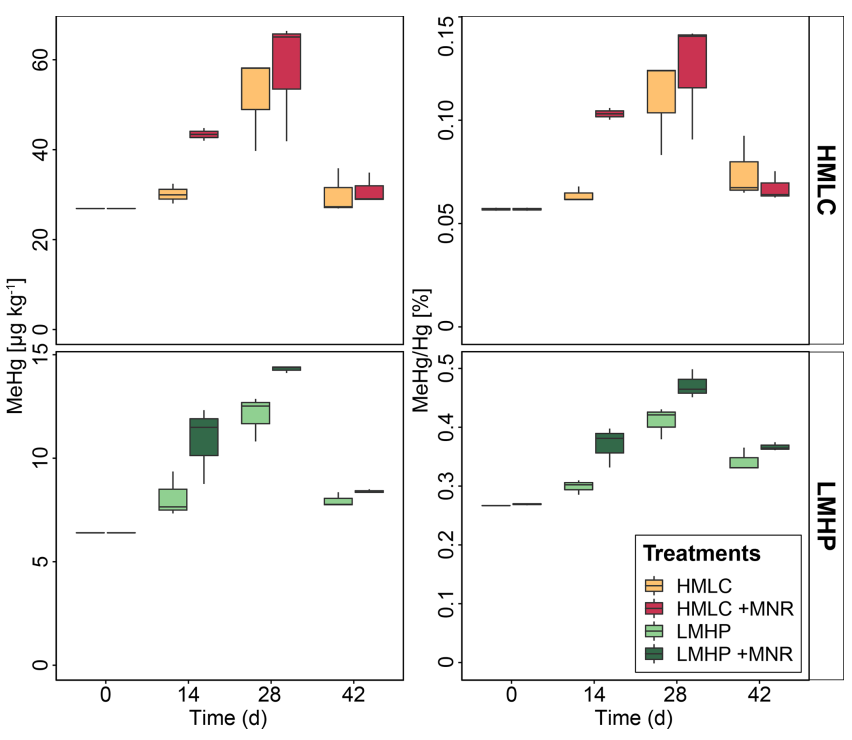

Figure 10. Soil $\mathrm{MeHg}$ concentrations and $\mathrm{MeHg} / \mathrm{Hg}$ ratios over the course of the experiment for cornfield soils (HMLC, yellow/red) and pasture field soils (LMHC, lime/green). The highest net methylation was observed during first flooding for + MNR treatments and during the draining period for microcosms without manure addition. A significant decrease in $\mathrm{MeHg} / \mathrm{Hg}$ was observed during the second flooding for all treatments.

2015). The formation and aggregation of $\beta-\mathrm{HgS}_{(\mathrm{s})}$ are further supported by AF4 results (Sect. 4.2).

Hofacker et al. (2013) reported a quantitatively relevant incorporation of $\mathrm{Hg}$ into metallic $\mathrm{Cu}^{0}$ particles. However, we do not consider this a relevant pathway, due to the relatively high $\mathrm{Hg} / \mathrm{Cu}_{\text {molar }}$ ratio in our soil compared to Hofacker et al. (2013). Although the simultaneous decrease in $\mathrm{Hg}$ and $\mathrm{Cu}$ may be interpreted as the immobilization of $\mathrm{Hg}$ through incorporation into metallic $\mathrm{Cu}$ particles, (i) we did not observe the formation of colloidal $\mathrm{Cu}$ associated with $\mathrm{Hg}$, and (ii) relatively high $\mathrm{Hg} / \mathrm{Cu}$ molar ratios indicate that the decrease in $\mathrm{Hg}$ in the soil solution cannot be solely explained by this mechanism as $\mathrm{Hg}$ would be marginally incorporated into metallic $\mathrm{Cu}^{0}$ particles.

Also, $\mathrm{Hg}$ in soil solutions is volatilized by reduction of $\mathrm{Hg}^{2+}$ to $\mathrm{Hg}^{0}$ (Hindersmann et al., 2014; Poulin et al., 2016; $\mathrm{Li}$ et al., 2021). Our experimental design did not allow for quantification of gaseous $\mathrm{Hg}^{0}$, and it may have exited the microcosms since they were only sealed with Parafilm. Reduction of $\mathrm{Hg}^{2+}$ may happen both biotically (Grégoire and Poulain, 2018) and abiotically under UV light and in the dark (Allard and Arsenie, 1991). Biotic reduction is a detoxication mechanism of bacteria carrying $\mathrm{merA}$ genes in $\mathrm{Hg}$ polluted environments. Biotic volatilization has been observed in neighboring soils of our sampling site (Frossard et al., 2018). Organic amendments and high Hg levels have been shown to increase the abundance of $\mathrm{Hg}$-reducing bacteria (Hu et al., 2019). Further, dark abiotic reduction of $\mathrm{Hg}^{2+}$ 
complexed to functional groups of DOM in soils has been demonstrated (Jiang et al., 2015). However, it is unlikely that $\mathrm{Hg}$ reduction can solely explain the decrease in $\mathrm{Hg}$ in the soil solution in our microcosms. We therefore interpret the decrease in $\mathrm{Hg}$ concentration to be due to a combination of manure NOM complexation and sequestration together with the formation of $\mathrm{HgS}_{(\mathrm{s})}$ during flooding. Our data show that manure addition may have an immobilizing effect on $\mathrm{Hg}$ in flooded soils. By contrast, carbon amendments may increase $\mathrm{Hg}$ mobility and methylation in NOM-depleted and cinnabar-rich mountain soils (Eckley et al., 2021).

In the pasture field soil (LMHC), soil solution $\mathrm{Hg}$ concentrations remained at low levels $\left(<0.16 \mu \mathrm{g} \mathrm{L}^{-1} \mathrm{Hg}_{<0.02 \mu \mathrm{m}}\right)$ during the whole experiment in both treatments (Fig. 6a). Unlike in the cornfield soil (HMLC), we did not observe a simultaneous release of $\mathrm{Hg}$ upon Mn reduction (Fig. 5c). We explain this with the not completely $\mathrm{Hg}$-saturated NOM in this soil, if we assume that $0.1 \%-0.6 \%(w / w)$ of NOM was reduced $\mathrm{S}$ with a high affinity to $\mathrm{Hg}$ (Grigg et al., 2018; Ravichandran, 2004; Skyllberg, 2008). Thus, the pasture field soil has a rather limited pool of labile $\mathrm{Hg}$ compared to the cornfield soil. Both $\mathrm{Hg}_{<0.02 \mu \mathrm{m}}$ and $\mathrm{Hg}_{<10 \mu \mathrm{m}}$ negatively correlate with the sum of sampled soil solution $\left(R^{2}=-0.841, p=<0.001\right)$ during both flooding periods and decreased fast. This suggests that the concentration gradient between supernatant artificial rainwater and the soil solution contributed to the fast exhaustion of the small labile $\mathrm{Hg}$ pool in pasture field soil. The presence of this concentration gradient in our incubation setup is confirmed by the continuously decreasing concentrations of conservative ions $\left(\mathrm{Cl}^{-}, \mathrm{Na}^{+}, \mathrm{K}^{+}\right)$in soil solutions of the HMLC runs (Figs. S7, S8). The relatively high proportion of particulate $\mathrm{Hg}$ vastly decreased during the draining period (Fig. 3b, c), and we speculate that this change is a result of the mobilization of the POM-Hg pool by mineralization/degradation of NOM which sorbed $\mathrm{Hg}$ during the draining period (Jones et al., 2018). In summary, flooding of the pasture field soils mobilized only a small pool of particulate-bound $\mathrm{Hg}$, which was exhausted within the first flooding period.

\subsection{Colloidal Hg}

For runs without manure, AF4 results show that the $\mathrm{Hg}$ released from Mn oxyhydroxides (Sect. 4.1) was dominated by truly dissolved $\mathrm{Hg}\left(\mathrm{Hg}^{2+}\right.$ or LMW-NOM-Hg) (Fig. 8). The high $\mathrm{Cl}^{-}$concentrations (up to $800 \mathrm{mg} \mathrm{L}^{-1}$, Fig. S14) likely influenced the $\mathrm{Hg}$ speciation in the soil solution, as chloride is a main complexant for $\mathrm{Hg}^{2+}$ (Li et al., 2020; Gilli et al., 2018). During $\mathrm{Hg}$ release, the proportions of larger $\mathrm{Hg}$ colloids $(>25 \mathrm{~nm})$ decreased. The stable proportion of humic-substance-bound $\mathrm{Hg}$ and inorganic $\mathrm{Hg}$ colloids between 6 and $25 \mathrm{~nm}$ indicates that once released no major adsorption or aggregation of truly dissolved $\mathrm{Hg}$ and larger colloidal $\mathrm{Hg}$ occurs. Additional complexation of $\mathrm{Hg}$ by DOM can be excluded if we assume the saturation state of thiol sites of the NOM pool in the soil (Sect. 4.1). These observations illustrate the remarkably high $\mathrm{Hg}$ mobility and potentially increased bioavailability (proportion of truly dissolved $\mathrm{Hg}$ ) to $\mathrm{Hg}$-metabolizing microorganisms compared to other studies (Hofacker et al., 2013; Poulin et al., 2016). The authors either did not observe $\mathrm{Hg}$ in the truly dissolved form, or they observed a decrease to low levels within the first days of incubation. Overall, the released $\mathrm{Hg}$ from cornfield soil (HMLC) shows a high mobility and might represent a possible threat to downstream ecosystems and a source for $\mathrm{Hg}$ methylating bacteria. However, the total $\mathrm{Hg}$ released and sampled from soil solution represents a rather small pool $\left(12.8 \pm 4.2 \mu \mathrm{g} \mathrm{HgT} \mathrm{kg}^{-1}\right.$ soil) of the total $\mathrm{Hg}$ $\left(47.3 \pm 0.5 \mathrm{mg} \mathrm{kg}^{-1}\right)$. Further work would be needed to establish a $\mathrm{Hg}$ flux model to better understand in situ soil $\mathrm{Hg}$ mobility in these soils.

The manure addition had a key effect on the proportions of colloidal fractions in soil solution and overall led to a low proportion of truly dissolved fraction (Fig. 8). We suggest that the distinct fraction of colloids with $d_{\mathrm{h}}=6-25 \mathrm{~nm}$ represents metacinnabar-like $\mathrm{HgS}_{(\mathrm{s})}$ colloids (Gerbig et al., 2011). This is supported by the onset of sulfate reduction in phase 2 (Rivera et al., 2019; Poulin et al., 2016) and reported HgNOM interactions that may cause the precipitation of $\mathrm{Hg}$ bearing sulfide phases $\left(\mathrm{FeS}_{(\mathrm{s})}, \beta-\mathrm{HgS}_{(\mathrm{s})}\right)$ (Manceau et al., 2015). The size of $\beta-\mathrm{HgS}_{(\mathrm{s})}$ nanoparticles formed from free sulfide is dependent on the sulfide concentration as well as on the $\mathrm{Hg}$ : DOM ratio (Poulin et al., 2017). The formation of a distinct size fraction of $\mathrm{HgS}(\mathrm{s})$ has been experimentally observed at comparable $\mathrm{Hg}$ : DOM ratios (Gerbig et al., 2011). The Hg colloidal distribution was dominated by the presence of large fractions $\left(d_{\mathrm{h}}=30-450 \mathrm{~nm}\right)$. Larger organic acids with high aromaticity usually contain higher proportions of thiol groups than smaller molecules and selectively complex $\mathrm{Hg}$ (Haitzer et al., 2002). This suggests that Hg complexation is kinetically driven, and it can shift from LMW-DOM to larger NOM and larger aggregates of POM as supported by earlier incubation experiments (Poulin et al., 2016). We therefore interpret that the relative increase in $\mathrm{Hg}$ colloids with $d_{\mathrm{h}}=30-450 \mathrm{~nm}$ (Fig. 8) is caused by (1) complexation of the released dissolved $\mathrm{Hg}_{<1 \mathrm{kDa}}$ by strong binding sites of thiol-rich NOM in larger clay-organic-metal complexes and (2) the aggregation of $\mathrm{HgS}_{(\mathrm{s})}$ colloids during the experiment. Although the presence of humic substances and larger NOM was shown to narrow the size range of $\mathrm{HgS}_{(\mathrm{s})}$ nanoparticles precipitating from solution (Aiken et al., 2011), through time, these colloids may grow, aggregate and form clusters in a wide size distribution (Deonarine and Hsu-Kim, 2009; Poulin et al., 2017). Thus, their aggregation during the draining period may explain the decrease in monodisperse $\mathrm{Hg}$-bearing colloids, also leading to sequestration of $\mathrm{Hg}$ in the soil matrix, without remobilization during the second flooding. Our data suggest metacinnabar formation $(\beta$ $\left.\mathrm{HgS}_{(\mathrm{s})}\right)$ in a distinct size fraction $\left(d_{\mathrm{h}}=6-25\right)$ and their aggre- 
gation to large fractions $\left(d_{\mathrm{h}}=30-450 \mathrm{~nm}\right)$ at environmental conditions in real-world samples.

\subsection{Net MeHg production in soil}

The studied soils show uncommonly high initial MeHg levels $\left(6.4-26.9 \mu \mathrm{g} \mathrm{kg}^{-1}\right)$ when compared to other highly polluted mining or industrial legacy sites (Horvat et al., 2003; Neculita et al., 2005; Qiu et al., 2005; Fernández-Martínez et al., 2015), supposedly as a result of a flooding event prior to sampling resulting in a net $\mathrm{MeHg}$ production. Still, we observed significant net $\mathrm{MeHg}$ production during the first $28 \mathrm{~d}$ of the incubation, resulting in even higher $\mathrm{MeHg}$ concentrations of up to $44.81 \mathrm{\mu g} \mathrm{kg}^{-1}$ (Table 3; Fig. 10). Soils treated with manure showed a faster net $\mathrm{MeHg}$ production, with the highest increase in $\mathrm{MeHg}$ during the first flooding period. Controls showed the highest net $\mathrm{MeHg}$ production during the draining period and reached similar levels of MeHg at the start of the second flooding on day 28 (Fig. 10). For cornfield soil (HMLC), both treatments show a high concentration of bioavailable $\mathrm{Hg}^{2+}$ or $\mathrm{Hg}$ associated with labile NOM $\left(\mathrm{HgT}_{<0.02 \mu \mathrm{m}}>15 \mu \mathrm{g} \mathrm{L}^{-1}\right)$ in soil solution during the first flooding. Net $\mathrm{MeHg}$ production is therefore rather limited by cellular uptake of $\mathrm{Hg}$ or the microbial activity of methylating microorganisms than bioavailability. Thus, we interpreted the addition of labile carbon in the form of manure to result in a higher microbial activity and net $\mathrm{MeHg}$ production during the first flooding period. However, we neither assessed the activity nor the abundance of $\mathrm{Hg}$ methylating bacteria such as sulfate reducers (SRB), Fe reducers (FeRB), archaea or firmicutes (Gilmour et al., 2013). In the runs without manure addition, a substantial part of $\mathrm{Hg}$ was methylated during the draining period. This indicates that even if low concentrations of $\mathrm{Hg}$ are released (LMHC microcosms day 14: $\mathrm{HgT}_{<0.02 \mu \mathrm{m}}<50 \mathrm{ng} \mathrm{L}^{-1}$ ) a substantial amount of $\mathrm{Hg}$ can be methylated. Micro- and meso-pore spaces with steep redox gradients act as ideal environments for microbial methylation even in a drained and generally aerobic system (e.g., HMLC without manure during the draining period).

Further, we observed a decrease in absolute $\mathrm{MeHg}$ concentrations in all microcosms during the second flooding period. Oscillating net de-/methylation in environments characterized by flood-drought-flood cycles has been reported earlier (Marvin-DiPasquale et al., 2014). Degradation of MeHg was reported to happen either abiotically by photodegradation or biotically by chemotrophic reductive or oxidative demethylation by microorganisms carrying the mer operon (Grégoire and Poulain, 2018). Photodegradation of $\mathrm{MeHg}$ can be excluded as the experiment was conducted in the dark. However, demethylation could have happened as biotic reductive demethylation. A possible explanation is a $\mathrm{MeHg}$ detoxification reaction by microorganisms carrying the mer operon (merB) (Hu et al., 2019; Frossard et al., 2018; Dash and Das, 2012). However, we can only hypothesize about demethylation mechanisms, as neither communities (DNA) nor gene expression (mRNA) dynamics in the soils were analyzed during the experiment.

\subsection{Experimental limitations}

Incubation experiments on a laboratory scale are a common way to study the changes in mobility of trace elements in floodplain soils (Gilli et al., 2018; Frohne et al., 2011; Poulin et al., 2016; Abgottspon et al., 2015). These study designs allow for controlled conditions and replicable results. However, controlled experiments usually fail to cover the complexity of a real floodplain soil system (Ponting et al., 2020). Our study design did not involve temperature gradients, realistic hydrological flow conditions or intact soil structure. In this study, the artificial rainwater and the soil were equilibrated by shaking for a few minutes. However, the equilibration appeared to be incomplete with respect to highly soluble chloride-bearing minerals for the experiment with cornfield soil (Fig. S14). The incomplete equilibration is indicated by the temporal patterns of conservative ions $\left(\mathrm{Cl}^{-}, \mathrm{K}^{+}\right.$ and $\mathrm{Na}^{+}$) in soil solution (Figs. S7, S8) and the difference in $\mathrm{Cl}^{-}$concentration between the soil solutions at $t=6 \mathrm{~h}$ and the same water-soil mixture shaken for $6 \mathrm{~h}$ (Fig. S14). These patterns are a result of a concentration gradient between supernatant water and the solution in the soil pore space. They only became visible due to high levels of conservative ions to start with, which most likely stem from a fertilization event prior to sampling the soil. Infiltration of supernatant water was facilitated by the sampling of $4 \%-6 \%$ of the total added water at each time point. This resulted in a dilution of the soil solution. Consequently, the continuous decrease in sulfate was not directly indicative of sulfate reduction but rather the result of this dilution effect. However, this effect did not directly affect the release of soil bound elements (e.g., Hg, $\mathrm{Mn}, \mathrm{Fe}, \mathrm{As}$ ) by reductive dissolution (Figs. 2, 3, 4). It should also be noted that high initial $\mathrm{Cl}^{-}$concentrations in the soil solution may influence $\mathrm{Hg}$ solubility since $\mathrm{Cl}^{-}$is a complexant for $\mathrm{Hg}^{2+}$ (Li et al., 2020), and this warrants further studies on the role of inorganic fertilization in $\mathrm{Hg}$ mobility.

\section{Conclusions}

We studied the effect of manure addition on the mobility of $\mathrm{Hg}$ in soil during a flooding-draining experiment. We observed formation and size distribution changes of $\mathrm{Hg}$ colloids $\left(\beta-\mathrm{HgS}_{(\mathrm{s})}, \mathrm{Hg}-\mathrm{NOM}\right)$ at environmental conditions in soil solution by AF4-ICP-MS. The results of this study show that manure addition (1) diminished HgT mobility, (2) facilitated $\mathrm{Hg}$ complexation with fresh NOM and formation of $\beta-\mathrm{HgS}_{(\mathrm{s})}$, and (3) had only a limited effect on net MeHg production in polluted and periodically flooded soils.

Mercury was mobilized upon reductive dissolution of $\mathrm{Mn}$ oxyhydroxides in highly $\mathrm{Hg}$-polluted $\left(47.3 \pm 0.5 \mathrm{mg} \mathrm{kg}^{-1}\right)$ and NOM-poor soils. The application of manure accelerated 
Table 3. Soil $\mathrm{MeHg}$ concentrations and net methylation $(\mathrm{MeHg} / \mathrm{Hg}$ ) over the time of the experiment.

\begin{tabular}{lrrrrrrr}
\hline Treatment & Day & $n$ & $\begin{array}{r}\text { Mean } \\
\text { MeHg }\end{array}$ & $\begin{array}{r}\text { SD MeHg } \\
\left(\mu \mathrm{kg}^{-1}\right)\end{array}$ & $\begin{array}{r}\text { Range MeHg } \\
\left(\mu \mathrm{kg}^{-1}\right)\end{array}$ & $\begin{array}{r}\mathrm{MeHg} / \mathrm{Hg} \mathrm{T} \\
(\% \text { o })\end{array}$ & $\begin{array}{r}\text { Net MeHg } \\
\text { production } \\
(\%)\end{array}$ \\
\hline HMLC & 0 & 1 & 26.9 & - & $26.9-26.9$ & 0.57 & - \\
& 14 & 3 & 30.14 & 2.19 & $28.04-32.42$ & 0.64 & 12.0 \\
& 28 & 3 & 52.04 & 10.65 & $39.74-58.25$ & 1.1 & 73.1 \\
& 42 & 3 & 30.03 & 5.05 & $26.93-35.86$ & 0.75 & -32.4 \\
\hline HMLC+MNR & 0 & 1 & 26.9 & - & $26.9-26.9$ & 0.57 & - \\
& 14 & 3 & 43.41 & 1.99 & $42-44.81$ & 1.03 & 81.1 \\
& 28 & 3 & 57.79 & 13.79 & $41.88-66.41$ & 1.24 & 20.7 \\
& 42 & 3 & 30.94 & 3.43 & $28.85-34.9$ & 0.67 & -45.9 \\
\hline LMHC & 0 & 1 & 6.4 & - & $6.4-6.4$ & 2.72 & - \\
& 14 & 3 & 8.11 & 1.09 & $7.33-9.36$ & 2.99 & 10.0 \\
& 28 & 3 & 12.07 & 1.1 & $10.81-12.87$ & 4.11 & 37.2 \\
& 42 & 3 & 7.95 & 0.35 & $7.73-8.36$ & 3.42 & -16.7 \\
\hline LMHC+MNR & 0 & 1 & 6.4 & - & $6.4-6.4$ & 2.69 & - \\
& 14 & 3 & 10.86 & 1.86 & $8.76-12.32$ & 3.72 & 38.1 \\
& 28 & 3 & 14.31 & 0.17 & $14.12-14.43$ & 4.7 & 26.6 \\
& 42 & 3 & 8.4 & 0.09 & $8.33-8.5$ & 3.67 & -22.0 \\
\hline
\end{tabular}

the release of $\mathrm{Hg}$, facilitated the formation of colloidal $\mathrm{Hg}$ and exhausted the mobile $\mathrm{Hg}$ pool within the first $7 \mathrm{~d}$ of flooding. This prevented $\mathrm{Hg}$ remobilization during the second flooding period. Contrastingly, $\mathrm{Hg}$ was mainly released as particulate-bound $\mathrm{Hg}$ in soils with moderate $\mathrm{Hg}$ pollution $\left(2.4 \pm 0.3 \mathrm{~m} \mathrm{~kg}^{-1}\right)$ and high NOM levels, presumably due to its higher soil organic carbon content. This relatively small pool of particulate $\mathrm{Hg}$ was exhausted within the first flooding period. In both soils, soil reduction enhanced net $\mathrm{MeHg}$ production of a substantial part of the $\mathrm{Hg}$ pool as confirmed by $\mathrm{MeHg}$ formation upon flooding-draining cycles. However, $\mathrm{MeHg}$ was either subsequently removed from the soil by advective transport of dissolved $\mathrm{MeHg}$ in the soil column or transformed by reductive demethylation. We suggest that the temporal changes in net $\mathrm{MeHg}$ production are limited by microbial activity of $\mathrm{Hg}$ methylators, given the similar net $\mathrm{MeHg}$ production in treatments and soils with variable dissolved $\mathrm{Hg}$ levels. Microbial activity is likely to be stimulated by manure addition.

The release of $\mathrm{Hg}$ from polluted soils to downstream ecosystems does depend on both biogeochemical conditions and hydrological transport. Our experiment shows that redox oscillations (flooding-draining-flooding cycles) of a polluted floodplain soil are likely to induce pulses of both $\mathrm{Hg}$ and $\mathrm{MeHg}$ to the downstream ecosystems. This is supported with earlier studies (Poulin et al., 2016; Frohne et al., 2012; Hofacker et al., 2013). In contrast to NOM-rich soil systems, we show that the Mn dynamics may govern the release of $\mathrm{Hg}$ in highly polluted soil systems low in NOM. Further, the application of additional NOM in the form of manure facilitated soil reduction, contributed to the transformation of $\mathrm{Hg}$ towards less mobile species and reduced the $\mathrm{Hg}$ mobilization. However, effects of carbon amendments (organic amendments or biochar) are contrasting between enhancing (Li et al., 2019; Eckley et al., 2021) and diminishing (Beckers et al., 2019; Wang et al., 2020, 2021) Hg mobility. We therefore stress the need for characterization of soil properties and especially NOM in future studies focusing on $\mathrm{Hg}$ mobility upon organic amendments ( $\mathrm{Li}$ et al., 2019). We further emphasize the need for field trials integrating biogeochemical processes, hydrological transport and $\mathrm{Hg}$ soil-air exchange in order to establish $\mathrm{Hg}$ flux models to better understand in situ soil Hg mobility.

Data availability. Details of analytical methods and AF4-ICPMS fractograms are given in the Supplement. A complete dataset of the data used in this study is accessible at https://doi.org/10.5281/zenodo.4715110 (Gfeller et al., 2020).

Supplement. The supplement related to this article is available online at: https://doi.org/10.5194/bg-18-3445-2021-supplement.

Author contributions. AM and LG designed the study. LG and AW performed the incubation experiments. LG and IW performed laboratory analyses. LG and IW performed the data analysis. AM and VIS supervised and financed the study. LG prepared the manuscript with contributions from all co-authors. 
Competing interests. The authors declare that they have no conflict of interest.

Acknowledgements. We acknowledge Patrick Neuhaus, Jaime Caplette, Kevin Trindade, Killian Kavanagh and Daniela Fischer for the help in the laboratory. We thank Tobias Erhardt at the Climate and Environmental Physics (CEP) at University of Bern for the ICP-TOF-MS analyses, Urs Eggenberger for the access to the X-ray diffraction spectrometer, and Stephane Westermann at the Dienststelle für Umweltschutz (DUS) of the Canton Wallis for the help with site selection and sampling permissions. Soil temperatures have been provided by MeteoSwiss, the Swiss Federal Office of Meteorology and Climatology. Klaus Jarosch and Moritz Bigalke of the soil science group at the Institute of Geography at University of Bern gave valuable advice during the writing process.

Financial support. This work was funded the Swiss National Science Foundation (SNSF, grant no. 163661). Vera I. Slaveykova and Isabelle Worms were supported by the SNSF R'Equip project no. 183292 .

Review statement. This paper was edited by Perran Cook and reviewed by Brett Poulin and Jan G. Wiederhold.

\section{References}

Abgottspon, F., Bigalke, M., and Wilcke, W.: Fast colloidal and dissolved release of trace elements in a carbonatic soil after experimental flooding, Geoderma, 259-260, 156-163, https://doi.org/10.1016/j.geoderma.2015.06.005, 2015.

Aiken, G. R., Hsu-Kim, H., and Ryan, J. N.: Influence of dissolved organic matter on the environmental fate of metals, nanoparticles, and colloids, Environ. Sci. Technol., 45, 3196-3201, https://doi.org/10.1021/es103992s, 2011.

Åkerblom, S., Meili, M., Bringmark, L., Johansson, K., Kleja, D. B., and Bergkvist, B.: Partitioning of $\mathrm{Hg}$ Between Solid and Dissolved Organic Matter in the Humus Layer of Boreal Forests, Water Air Soil Poll., 189, 239-252, https://doi.org/10.1007/s11270-007-9571-1, 2008.

Allard, B. and Arsenie, I.: Abiotic reduction of mercury by humic substances in aquatic system: An important process for the mercury cycle, Water Air Soil Poll., 56, 457-464, https://doi.org/10.1007/BF00342291, 1991.

AMAP/UN Environment: Technical Background Report for the Global Mercury Assessment 2018, Arctic Monitoring and Assessment Programme, Oslo, Norway, UN Environment Programme, Chemicals and Health Branch, Geneva, Switzerland, 426 pp., 2019.

Amos, H. M., Jacob, D. J., Streets, D. G., and Sunderland, E. M.: Legacy impacts of all-time anthropogenic emissions on the global mercury cycle, Global Biogeochem. Cy., 27, 410-421, https://doi.org/10.1002/gbc.20040, 2013.

Beckers, F. and Rinklebe, J.: Cycling of mercury in the environment: Sources, fate, and human health implica- tions: A review, Crit. Rev. Env. Sci. Tec., 47, 693-794, https://doi.org/10.1080/10643389.2017.1326277, 2017.

Beckers, F., Mothes, S., Abrigata, J., Zhao, J., Gao, Y., and Rinklebe, J.: Mobilization of mercury species under dynamic laboratory redox conditions in a contaminated floodplain soil as affected by biochar and sugar beet factory lime, Sci. Total Environ., 672, 604-617, https://doi.org/10.1016/j.scitotenv.2019.03.401, 2019.

Biester, H., Müller, G., and Schöler, H. F.: Binding and mobility of mercury in soils contaminated by emissions from chlor-alkali plants, Sci. Total Environ., 284, 191-203, https://doi.org/10.1016/S0048-9697(01)00885-3, 2002.

Bigham, G. N., Murray, K. J., Masue-Slowey, Y., and Henry, E. A.: Biogeochemical controls on methylmercury in soils and sediments: Implications for site management, Integr. Environ. Asses., 13, 249-263, https://doi.org/10.1002/ieam.1822, 2017.

Bravo, A. G., Bouchet, S., Tolu, J., Björn, E., Mateos-Rivera, A., and Bertilsson, S.: Molecular composition of organic matter controls methylmercury formation in boreal lakes, Nat. Commun., 8 , 14255, https://doi.org/10.1038/ncomms14255, 2017.

Chiasson-Gould, S. A., Blais, J. M., and Poulain, A. J.: Dissolved organic matter kinetically controls mercury bioavailability to bacteria, Environ. Sci. Technol., 48, 3153-3161, https://doi.org/10.1021/es4038484, 2014.

Dash, H. R. and Das, S.: Bioremediation of mercury and the importance of bacterial mer genes, Int. Biodeter. Biodegr., 75, 207213, https://doi.org/10.1016/j.ibiod.2012.07.023, 2012.

Deonarine, A. and Hsu-Kim, H.: Precipitation of Mercuric Sulfide Nanoparticles in NOM-Containing Water: Implications for the Natural Environment, Environ. Sci. Technol., 43, 2368-2373, https://doi.org/10.1021/es803130h, 2009.

Deonarine, A., Lau, B. L. T., Aiken, G. R., Ryan, J. N., and HsuKim, H.: Effects of humic substances on precipitation and aggregation of zinc sulfide nanoparticles, Environ. Sci. Technol., 45, 3217-3223, https://doi.org/10.1021/es1029798, 2011.

Driscoll, C. T., Mason, R. P., Chan, H. M., Jacob, D. J., and Pirrone, N.: Mercury as a global pollutant: Sources, pathways, and effects, Environ. Sci. Technol., 47, 4967-4983, https://doi.org/10.1021/es305071v, 2013.

Drott, A., Lambertsson, L., Björn, E., and Skyllberg, U.: Importance of Dissolved Neutral Mercury Sulfides for Methyl Mercury Production in Contaminated Sediments, Environ. Sci. Technol., 41, 2270-2276, https://doi.org/10.1021/es061724z, 2007.

Dublet, G., Worms, I., Frutschi, M., Brown, A., Zünd, G. C., Bartova, B., Slaveykova, V. I., and Bernier-Latmani, R.: Colloidal Size and Redox State of Uranium Species in the Porewater of a Pristine Mountain Wetland, Environ. Sci. Technol., 53, 93619369, https://doi.org/10.1021/acs.est.9b01417, 2019.

Eckley, C. S., Luxton, T. P., Stanfield, B., Baldwin, A., Holloway, J., McKernan, J., and Johnson, M. G.: Effect of organic matter concentration and characteristics on mercury mobilization and methylmercury production at an abandoned mine site, Environ. Pollut., 271, 116369, https://doi.org/10.1016/j.envpol.2020.116369, 2021.

Eklöf, K., Bishop, K., Bertilsson, S., Björn, E., Buck, M., Skyllberg, U., Osman, O. A., Kronberg, R.-M., and Bravo, A. G.: Formation of mercury methylation hotspots as a consequence of forestry operations, Sci. Total Environ., 613-614, 1069-1078, https://doi.org/10.1016/j.scitotenv.2017.09.151, 2018. 
Fernández-Martínez, R., Larios, R., Gómez-Pinilla, I., GómezMancebo, B., López-Andrés, S., Loredo, J., Ordóñez, A., and Rucandio, I.: Mercury accumulation and speciation in plants and soils from abandoned cinnabar mines, Geoderma, 253-254, 3038, https://doi.org/10.1016/j.geoderma.2015.04.005, 2015.

Frohne, T., Rinklebe, J., Diaz-Bone, R. A., and Du Laing, G.: Controlled variation of redox conditions in a floodplain soil: Impact on metal mobilization and biomethylation of arsenic and antimony, Geoderma, 160, 414-424, https://doi.org/10.1016/j.geoderma.2010.10.012, 2011.

Frohne, T., Rinklebe, J., Langer, U., Du Laing, G., Mothes, S., and Wennrich, R.: Biogeochemical factors affecting mercury methylation rate in two contaminated floodplain soils, Biogeosciences, 9, 493-507, https://doi.org/10.5194/bg-9-493-2012, 2012.

Frossard, A., Donhauser, J., Mestrot, A., Gygax, S., Bååth, E., and Frey, B.: Long- and short-term effects of mercury pollution on the soil microbiome, Soil Biol. Biochem., 120, 191-199, https://doi.org/10.1016/j.soilbio.2018.01.028, 2018.

Gerbig, C. A., Kim, C. S., Stegemeier, J. P., Ryan, J. N., and Aiken, G. R.: Formation of nanocolloidal metacinnabar in mercuryDOM-sulfide systems, Environ. Sci. Technol., 45, 9180-9187, https://doi.org/10.1021/es201837h, 2011.

Gfeller, L., Weber, A., Worms, I., Slaveykova, V. I., and Mestrot, A.: Mercury mobility, colloid formation and methylation in a polluted fluvisol as affected by manure application and flooding-draining cycle [dataset], Zenodo, https://doi.org/10.5281/zenodo.4715110, 2020.

Gilli, R., Karlen, C., Weber, M., Rüegg, J., Barmettler, K., Biester, H., Boivin, P., and Kretzschmar, R.: Speciation and Mobility of Mercury in Soils Contaminated by Legacy Emissions from a Chemical Factory in the Rhône Valley in Canton of Valais, Switzerland, Soil Systems, 2, 44, https://doi.org/10.3390/soilsystems2030044, 2018.

Gilmour, C. C., Podar, M., Bullock, A. L., Graham, A. M., Brown, S. D., Somenahally, A. C., Johs, A., Hurt, R. A., Bailey, K. L., and Elias, D. A.: Mercury methylation by novel microorganisms from new environments, Environ. Sci. Technol., 47, 1181011820, https://doi.org/10.1021/es403075t, 2013.

Glenz, C. and Escher, J.-R.: Voruntersuchung von belasteten Standorten: Historische Untersuchung Objekt Grossgrundkanal, FUAG-Forum Umwelt AG, Visp, Switzerland, 89 pp., 2011.

Graham, A. M., Aiken, G. R., and Gilmour, C. C.: Dissolved organic matter enhances microbial mercury methylation under sulfidic conditions, Environ. Sci. Technol., 46, 2715-2723, https://doi.org/10.1021/es203658f, 2012.

Graham, A. M., Aiken, G. R., and Gilmour, C. C.: Effect of dissolved organic matter source and character on microbial $\mathrm{Hg}$ methylation in Hg-S-DOM solutions, Environ. Sci. Technol., 47, 5746-5754, https://doi.org/10.1021/es400414a, 2013.

Grégoire, D. S. and Poulain, A. J.: Shining light on recent advances in microbial mercury cycling, Facets, 3, 858-879, https://doi.org/10.1139/facets-2018-0015, 2018.

Grigg, A. R. C., Kretzschmar, R., Gilli, R. S., and Wiederhold, J. G.: Mercury isotope signatures of digests and sequential extracts from industrially contaminated soils and sediments, Sci. Total Environ., 636, 1344-1354, https://doi.org/10.1016/j.scitotenv.2018.04.261, 2018.

Guedron, S., Grangeon, S., Lanson, B., and Grimaldi, M.: Mercury speciation in a tropical soil association, Consequence of gold mining on $\mathrm{Hg}$ distribution in French Guiana, Geoderma, 153, 331-346, https://doi.org/10.1016/j.geoderma.2009.08.017, 2009.

Gygax, S., Gfeller, L., Wilcke, W., and Mestrot, A.: Emerging investigator series: mercury mobility and methylmercury formation in a contaminated agricultural flood plain: influence of flooding and manure addition, Environ. Sci.-Proc. Imp., 21, 2008-2019, https://doi.org/10.1039/c9em00257j, 2019.

Haitzer, M., Aiken, G. R., and Ryan, J. N.: Binding of mercury(II) to dissolved organic matter: the role of the mercuryto-DOM concentration ratio, Environ. Sci. Technol., 36, 35643570, https://doi.org/10.1021/es025699i, 2002.

Hindersmann, I., Hippler, J., Hirner, A. V., and Mansfeldt, T.: Mercury volatilization from a floodplain soil during a simulated flooding event, J. Soils Sediments, 14, 1549-1558, https://doi.org/10.1007/s11368-014-0908-2, 2014.

Hofacker, A. F., Voegelin, A., Kaegi, R., and Kretzschmar, R.: Mercury mobilization in a flooded soil by incorporation into metallic copper and metal sulfide nanoparticles, Environ. Sci. Technol., 47, 7739-7746, https://doi.org/10.1021/es4010976, 2013.

Hofacker, A. F., Behrens, S., Voegelin, A., Kaegi, R., LösekannBehrens, T., Kappler, A., and Kretzschmar, R.: Clostridium Species as Metallic Copper-Forming Bacteria in Soil under Reducing Conditions, Geomicrobiol. J., 32, 130-139, https://doi.org/10.1080/01490451.2014.933287, 2015.

Hojdová, M., Rohovec, J., Chrastný, V., Penížek, V., and Navrátil, T.: The influence of sample drying procedures on mercury concentrations analyzed in soils, B. Environ. Contam. Tox., 94, 570576, https://doi.org/10.1007/s00128-015-1521-9, 2015.

Horvat, M., Nolde, N., Fajon, V., Jereb, V., Logar, M., Lojen, S., Jacimovic, R., Falnoga, I., Liya, Q., Faganeli, J., and Drobne, D.: Total mercury, methylmercury and selenium in mercury polluted areas in the province Guizhou, China, Sci. Total Environ., 304, 231-256, https://doi.org/10.1016/S0048-9697(02)00572-7, 2003.

Hu, H., Li, M., Wang, G., Drosos, M., Li, Z., Hu, Z., and $\mathrm{Xi}, \mathrm{B} .:$ Water-soluble mercury induced by organic amendments affected microbial community assemblage in mercury-polluted paddy soil, Chemosphere, 236, 124405, https://doi.org/10.1016/j.chemosphere.2019.124405, 2019.

Jiang, T., Skyllberg, U., Wei, S., Wang, D., Lu, S., Jiang, Z., and Flanagan, D. C.: Modeling of the structure-specific kinetics of abiotic, dark reduction of $\mathrm{Hg}$ (II) complexed by $\mathrm{O} / \mathrm{N}$ and $\mathrm{S}$ functional groups in humic acids while accounting for timedependent structural rearrangement, Geochim. Cosmochim. Ac., 154, 151-167, https://doi.org/10.1016/j.gca.2015.01.011, 2015.

Jiskra, M., Wiederhold, J. G., Skyllberg, U., Kronberg, R.M., and Kretzschmar, R.: Source tracing of natural organic matter bound mercury in boreal forest runoff with mercury stable isotopes, Environ. Sci.-Proc. Imp., 19, 1235-1248, https://doi.org/10.1039/c7em00245a, 2017.

Jones, M. E., Nico, P. S., Ying, S., Regier, T., Thieme, J., and Keiluweit, M.: Manganese-Driven Carbon Oxidation at OxicAnoxic Interfaces, Environ. Sci. Technol., 52, 12349-12357, https://doi.org/10.1021/acs.est.8b03791, 2018.

Jonsson, S., Skyllberg, U., Nilsson, M. B., Westlund, P.O., Shchukarev, A., Lundberg, E., and Björn, E.: Mercury methylation rates for geochemically relevant $\mathrm{Hg}(\mathrm{II})$ 
species in sediments, Environ. Sci. Technol., 46, 11653-11659, https://doi.org/10.1021/es3015327, 2012.

Kronberg, R.-M., Jiskra, M., Wiederhold, J. G., Björn, E., and Skyllberg, U.: Methyl Mercury Formation in Hillslope Soils of Boreal Forests: The Role of Forest Harvest and Anaerobic Microbes, Environ. Sci. Technol., 50, 9177-9186, https://doi.org/10.1021/acs.est.6b00762, 2016.

Lazareva, O., Sparks, D. L., Landis, R., Ptacek, C. J., and Ma, J.: Investigation of legacy industrial mercury in floodplain soils: South River, Virginia, USA, Environ. Earth Sci., 78, 246, https://doi.org/10.1007/s12665-019-8253-9, 2019.

Li, H., Zheng, D., Zhang, X., Niu, Z., Ma, H., Zhang, S., and Wu, C.: Total and Methylmercury of Suaeda heteroptera Wetland Soil Response to a Salinity Gradient Under Wetting and Drying Conditions, B. Environ. Contam. Tox., 104, 778-785, https://doi.org/10.1007/s00128-020-02874-1, 2020.

Li, M., Drosos, M., Hu, H., He, X., Wang, G., Zhang, H., Hu, $\mathrm{Z}$., and $\mathrm{Xi}, \mathrm{B}$. : Organic amendments affect dissolved organic matter composition and mercury dissolution in pore waters of mercury-polluted paddy soil, Chemosphere, 232, 356-365, https://doi.org/10.1016/j.chemosphere.2019.05.234, 2019.

Li, R., Qi, L., Ibeanusi, V., Badisa, V., Brooks, S., and Chen, G.: Reduction and bacterial adsorption of dissolved mercuric ion by indigenous bacteria at the Oak Ridge Reservation site, Chemosphere, 280, 130629, https://doi.org/10.1016/j.chemosphere.2021.130629, 2021.

Liang, X., Lu, X., Zhao, J., Liang, L., Zeng, E. Y., and Gu, B.: Stepwise Reduction Approach Reveals Mercury Competitive Binding and Exchange Reactions within Natural Organic Matter and Mixed Organic Ligands, Environ. Sci. Technol., 53, 1068510694, https://doi.org/10.1021/acs.est.9b02586, 2019.

Liu, S., Wang, J., Pu, S., Blagodatskaya, E., Kuzyakov, Y., and Razavi, B. S.: Impact of manure on soil biochemical properties: A global synthesis, Sci. Total Environ., 745, 141003, https://doi.org/10.1016/j.scitotenv.2020.141003, 2020.

Liu, Y.-R., Dong, J.-X., Han, L.-L., Zheng, Y.-M., and He, J.$\mathrm{Z}$.: Influence of rice straw amendment on mercury methylation and nitrification in paddy soils, Environ. Pollut., 209, 53-59, https://doi.org/10.1016/j.envpol.2015.11.023, 2016.

Ma, D., Wu, J., Yang, P., and Zhu, M.: Coupled Manganese Redox Cycling and Organic Carbon Degradation on Mineral Surfaces, Environ. Sci. Technol., 54, 8801--8810, https://doi.org/10.1021/acs.est.0c02065, 2020.

Manceau, A., Nagy, K. L., Marcus, M. A., Lanson, M., Geoffroy, N., Jacquet, T., and Kirpichtchikova, T.: Formation of metallic copper nanoparticles at the soil-root interface, Environ. Sci. Technol., 42, 1766-1772, https://doi.org/10.1021/es072017o, 2008.

Manceau, A., Lemouchi, C., Enescu, M., Gaillot, A.-C., Lanson, M., Magnin, V., Glatzel, P., Poulin, B. A., Ryan, J. N., Aiken, G. R., Gautier-Luneau, I., and Nagy, K. L.: Formation of Mercury Sulfide from $\mathrm{Hg}(\mathrm{II})$-Thiolate Complexes in Natural Organic Matter, Environ. Sci. Technol., 49, 9787-9796, https://doi.org/10.1021/acs.est.5b02522, 2015.

Marvin-DiPasquale, M., Windham-Myers, L., Agee, J. L., Kakouros, E., Le Kieu, H., Fleck, J. A., Alpers, C. N., and Stricker, C. A.: Methylmercury production in sediment from agricultural and non-agricultural wetlands in the Yolo By- pass, California, USA, Sci. Total Environ., 484, 288-299, https://doi.org/10.1016/j.scitotenv.2013.09.098, 2014.

Miller, C. L., Mason, R. P., Gilmour, C. C., and Heyes, A.: Influence of dissolved organic matter on the complexation of $\mathrm{Hg}$ under sulfidic conditions, Environ. Toxicol. Chem., 26, 624-633, 2007.

Miller, C. L., Southworth, G., Brooks, S., Liang, L., and $\mathrm{Gu}$, B.: Kinetic controls on the complexation between mercury and dissolved organic matter in a contaminated environment, Environ. Sci. Technol., 43, 8548-8553, https://doi.org/10.1021/es901891t, 2009.

Neculita, C.-M., Zagury, G. J., and Deschênes, L.: Mercury speciation in highly contaminated soils from chlor-alkali plants using chemical extractions, J. Environ. Qual., 34, 255-262, 2005.

Pham, A. L.-T., Morris, A., Zhang, T., Ticknor, J., Levard, C., and Hsu-Kim, H.: Precipitation of nanoscale mercuric sulfides in the presence of natural organic matter: Structural properties, aggregation, and biotransformation, Geochim. Cosmochim. Ac., 133, 204-215, https://doi.org/10.1016/j.gca.2014.02.027, 2014.

Ponting, J., Kelly, T. J., Verhoef, A., Watts, M. J., and Sizmur, T.: The impact of increased flooding occurrence on the mobility of potentially toxic elements in floodplain soil - A review, Sci. Total Environ., 754, 142040, https://doi.org/10.1016/j.scitotenv.2020.142040, 2020.

Poulin, B. A., Aiken, G. R., Nagy, K. L., Manceau, A., Krabbenhoft, D. P., and Ryan, J. N.: Mercury transformation and release differs with depth and time in a contaminated riparian soil during simulated flooding, Geochim. Cosmochim. Ac., 176, 118-138, https://doi.org/10.1016/j.gca.2015.12.024, 2016.

Poulin, B. A., Gerbig, C. A., Kim, C. S., Stegemeier, J. P., Ryan, J. N., and Aiken, G. R.: Effects of Sulfide Concentration and Dissolved Organic Matter Characteristics on the Structure of Nanocolloidal Metacinnabar, Environ. Sci. Technol., 51, 1313313142, https://doi.org/10.1021/acs.est.7b02687, 2017.

Qiu, G., Feng, X., Wang, S., and Shang, L.: Mercury and methylmercury in riparian soil, sediments, mine-waste calcines, and moss from abandoned $\mathrm{Hg}$ mines in east Guizhou province, southwestern China, Appl. Geochem., 20, 627-638, https://doi.org/10.1016/j.apgeochem.2004.09.006, 2005.

Ravichandran, M.: Interactions between mercury and dissolved organic matter - a review, Chemosphere, 55, 319-331, https://doi.org/10.1016/j.chemosphere.2003.11.011, 2004.

Ravichandran, M., Aiken, G. R., Reddy, M. M., and Ryan, J. N.: Enhanced Dissolution of Cinnabar (Mercuric Sulfide) by Dissolved Organic Matter Isolated from the Florida Everglades, Environ. Sci. Technol., 32, 3305-3311, https://doi.org/10.1021/es9804058, 1998.

Ravichandran, M., Aiken, G. R., Ryan, J. N., and Reddy, M. M.: Inhibition of Precipitation and Aggregation of Metacinnabar (Mercuric Sulfide) by Dissolved Organic Matter Isolated from the Florida Everglades, Environ. Sci. Technol., 33, 1418-1423, https://doi.org/10.1021/es9811187, 1999.

Remucal, C. K. and Ginder-Vogel, M.: A critical review of the reactivity of manganese oxides with organic contaminants, Environ. Sci.-Proc. Imp., 16, 1247-1266, https://doi.org/10.1039/c3em00703k, 2014.

Richner, W. and Sinaj, S.: Grundlagen für die Düngung landwirtschaflticher Kulturen in der Schweiz (GRUD 2017), Agroscope, Bern, Switzerland, 276 pp., 2017. 
Rivera, N. A., Bippus, P. M., and Hsu-Kim, H.: Relative Reactivity and Bioavailability of Mercury Sorbed to or Coprecipitated with Aged Iron Sulfides, Environ. Sci. Technol., 53, 7391-7399, https://doi.org/10.1021/acs.est.9b00768, 2019.

Siemens, J. and Kaupenjohann, M.: Dissolved organic carbon is released from sealings and glues of pore-water samplers, Soil Sci. Soc. Am. J., 67, 795-797, 2003.

Singer, M. B., Harrison, L. R., Donovan, P. M., Blum, J. D., and Marvin-DiPasquale, M.: Hydrologic indicators of hot spots and hot moments of mercury methylation potential along river corridors, Sci. Total Environ., 568, 697-711, https://doi.org/10.1016/j.scitotenv.2016.03.005, 2016.

Skyllberg, U.: Competition among thiols and inorganic sulfides and polysulfides for $\mathrm{Hg}$ and $\mathrm{MeHg}$ in wetland soils and sediments under suboxic conditions: Illumination of controversies and implications for MeHg net production, J. Geophys. Res.-Biogeo., 113, G00C03, https://doi.org/10.1029/2008JG000745, 2008.

Skyllberg, U. and Drott, A.: Competition between disordered iron sulfide and natural organic matter associated thiols for mercury(II) - an EXAFS study, Environ. Sci. Technol., 44, 12541259, https://doi.org/10.1021/es902091w, 2010.

Skyllberg, U., Bloom, P. R., Qian, J., Lin, C.-M., and Bleam, W. F.: Complexation of mercury(II) in soil organic matter: EXAFS evidence for linear two-coordination with reduced sulfur groups, Environ. Sci. Technol., 40, 4174-4180, https://doi.org/10.1021/es0600577, 2006.

Sunda, W. G. and Kieber, D. J.: Oxidation of humic substances by manganese oxides yields low-molecular-weight organic substrates, Nature, 367, 62-64, 1994.

Tang, W., Hintelmann, H., Gu, B., Feng, X., Liu, Y., Gao, Y., Zhao, J., Zhu, H., Lei, P., and Zhong, H.: Increased Methylmercury Accumulation in Rice after Straw Amendment, Environ. Sci. Technol., 53, 6144-6153, https://doi.org/10.1021/acs.est.8b07145, 2019

Tang, Z., Fan, F., Wang, X., Shi, X., Deng, S., and Wang, D.: Mercury in rice (Oryza sativa L.) and rice-paddy soils under longterm fertilizer and organic amendment, Ecotox. Environ. Safe., 150, 116-122, https://doi.org/10.1016/j.ecoenv.2017.12.021, 2018.

Vlassopoulos, D., Kanematsu, M., Henry, E. A., Goin, J., Leven, A., Glaser, D., Brown, S. S., and O'Day, P. A.: Manganese(iv) oxide amendments reduce methylmercury concentrations in sediment porewater, Environ. Sci.-Proc. Imp., 20, 1746-1760, https://doi.org/10.1039/c7em00583k, 2018.
Wang, A. O., Ptacek, C. J., Paktunc, D., Mack, E. E., and Blowes, D. W.: Application of biochar prepared from ethanol refinery by-products for $\mathrm{Hg}$ stabilization in floodplain soil: Impacts of drying and rewetting, Environ. Pollut., 267, 115396, https://doi.org/10.1016/j.envpol.2020.115396, 2020.

Wang, A. O., Ptacek, C. J., Mack, E. E., and Blowes, D. W.: Impact of multiple drying and rewetting events on biochar amendments for $\mathrm{Hg}$ stabilization in floodplain soil from South River, VA, Chemosphere, 262, 127794, https://doi.org/10.1016/j.chemosphere.2020.127794, 2021.

Wang, Y., Dang, F., Zhong, H., Wei, Z., and Li, P.: Effects of sulfate and selenite on mercury methylation in a mercury-contaminated rice paddy soil under anoxic conditions, Environ. Sci. Pollut. R., 23, 4602-4608, https://doi.org/10.1007/s11356-015-5696-8, 2016.

Wang, Y., Chen, Z., Wu, Y., and Zhong, H.: Comparison of methylmercury accumulation in wheat and rice grown in straw-amended paddy soil, Sci. Total Environ., 697, 134143, https://doi.org/10.1016/j.scitotenv.2019.134143, 2019.

Weber, F.-A., Voegelin, A., Kaegi, R., and Kretzschmar, R.: Contaminant mobilization by metallic copper and metal sulphide colloids in flooded soil, Nat. Geosci., 2, 267-271, https://doi.org/10.1038/ngeo476, 2009.

Zhang, T., Kim, B., Levard, C., Reinsch, B. C., Lowry, G. V., Deshusses, M. A., and Hsu-Kim, H.: Methylation of mercury by bacteria exposed to dissolved, nanoparticulate, and microparticulate mercuric sulfides, Environ. Sci. Technol., 46, 6950-6958, https://doi.org/10.1021/es203181m, 2012.

Zhang, Y., Liu, Y.-R., Lei, P., Wang, Y.-J., and Zhong, H.: Biochar and nitrate reduce risk of methylmercury in soils under straw amendment, Sci. Total Environ., 619-620, 384-390, https://doi.org/10.1016/j.scitotenv.2017.11.106, 2018.

Zhao, J.-Y., Ye, Z.-H., and Zhong, H.: Rice root exudates affect microbial methylmercury production in paddy soils, Environ. Pollut., 242, 1921-1929, https://doi.org/10.1016/j.envpol.2018.07.072, 2018.

Zhu, H., Zhong, H., and Wu, J.: Incorporating rice residues into paddy soils affects methylmercury accumulation in rice, Chemosphere, 152, 259-264, https://doi.org/10.1016/j.chemosphere.2016.02.095, 2016. 